\title{
Nine years of global hydrocarbon emissions based on source inversion of OMI formaldehyde observations
}

\author{
Maite Bauwens $^{1}$, Trissevgeni Stavrakou ${ }^{1}$, Jean-François Müller ${ }^{1}$, Isabelle De Smedt ${ }^{1}$, Michel Van Roozendael ${ }^{1}$, \\ Guido R. van der Werf ${ }^{2}$, Christine Wiedinmyer ${ }^{3}$, Johannes W. Kaiser ${ }^{4}$, Katerina Sindelarova ${ }^{5,6}$, and Alex Guenther ${ }^{7}$ \\ ${ }^{1}$ Royal Belgian Institute for Space Aeronomy, Avenue Circulaire 3, 1180 Brussels, Belgium \\ ${ }^{2}$ Vrije Universiteit Amsterdam, Faculty of Earth and Life Sciences, Amsterdam, the Netherlands \\ ${ }^{3}$ National Centre for Atmospheric Research, Boulder, CO, USA \\ ${ }^{4}$ Max Planck Institute for Chemistry, Mainz, Germany \\ ${ }^{5}$ UPMC Univ. Paris 06, Université Versailles St-Quentin, CNRS/INSU, LATMOS-IPSL, Paris, France \\ ${ }^{6}$ Charles University in Prague, Department of Atmospheric Physics, Prague, Czech Republic \\ ${ }^{7}$ University of California, Irvine, USA
}

Correspondence to: Maite Bauwens (maite.bauwens@aeronomie.be)

Received: 14 March 2016 - Published in Atmos. Chem. Phys. Discuss.: 31 March 2016

Revised: 23 June 2016 - Accepted: 8 July 2016 - Published: 11 August 2016

\begin{abstract}
As formaldehyde (HCHO) is a high-yield product in the oxidation of most volatile organic compounds (VOCs) emitted by fires, vegetation, and anthropogenic activities, satellite observations of $\mathrm{HCHO}$ are well-suited to inform us on the spatial and temporal variability of the underlying VOC sources. The long record of space-based $\mathrm{HCHO}$ column observations from the Ozone Monitoring Instrument (OMI) is used to infer emission flux estimates from pyrogenic and biogenic volatile organic compounds (VOCs) on the global scale over 2005-2013. This is realized through the method of source inverse modeling, which consists in the optimization of emissions in a chemistry-transport model (CTM) in order to minimize the discrepancy between the observed and modeled HCHO columns. The top-down fluxes are derived in the global CTM IMAGESv2 by an iterative minimization algorithm based on the full adjoint of IMAGESv2, starting from a priori emission estimates provided by the newly released GFED4s (Global Fire Emission Database, version 4s) inventory for fires, and by the MEGAN-MOHYCAN inventory for isoprene emissions. The top-down fluxes are compared to two independent inventories for fire (GFAS and FINNv1.5) and isoprene emissions (MEGAN-MACC and GUESS-ES).

The inversion indicates a moderate decrease (ca. 20\%) in the average annual global fire and isoprene emissions, from $2028 \mathrm{Tg} \mathrm{C}$ in the a priori to $1653 \mathrm{Tg} \mathrm{C}$ for burned biomass, and from 343 to $272 \mathrm{Tg}$ for isoprene fluxes. Those estimates
\end{abstract}

are acknowledged to depend on the accuracy of formaldehyde data, as well as on the assumed fire emission factors and the oxidation mechanisms leading to $\mathrm{HCHO}$ production. Strongly decreased top-down fire fluxes (30-50\%) are inferred in the peak fire season in Africa and during years with strong a priori fluxes associated with forest fires in Amazonia (in 2005, 2007, and 2010), bushfires in Australia (in 2006 and 2011), and peat burning in Indonesia (in 2006 and 2009), whereas generally increased fluxes are suggested in Indochina and during the 2007 fires in southern Europe. Moreover, changes in fire seasonal patterns are suggested; e.g., the seasonal amplitude is reduced over southeast Asia. In Africa, the inversion indicates increased fluxes due to agricultural fires and decreased maxima when natural fires are dominant. The top-down fire emissions are much better correlated with MODIS fire counts than the a priori inventory in regions with small and agricultural fires, indicating that the OMI-based inversion is well-suited to assess the associated emissions.

Regarding biogenic sources, significant reductions in isoprene fluxes are inferred in tropical ecosystems (30-40\%), suggesting overestimated basal emission rates in those areas in the bottom-up inventory, whereas strongly positive isoprene emission updates are derived over semiarid and desert areas, especially in southern Africa and Australia. This finding suggests that the parameterization of the soil 
moisture stress used in MEGAN greatly exaggerates the flux reduction due to drought in those regions. The isoprene emission trends over 2005-2013 are often enhanced after optimization, with positive top-down trends in Siberia $\left(4.2 \%\right.$ year $\left.^{-1}\right)$ and eastern Europe $\left(3.9 \%\right.$ year $\left.^{-1}\right)$, likely reflecting forest expansion and warming temperatures, and negative trends in Amazonia $\left(-2.1 \%\right.$ year $\left.^{-1}\right)$, south China $\left(-1 \%\right.$ year $\left.^{-1}\right)$, the United States $\left(-3.7 \%\right.$ year $\left.^{-1}\right)$, and western Europe $\left(-3.3 \%\right.$ year $\left.^{-1}\right)$, which are generally corroborated by independent studies, yet their interpretation warrants further investigation.

\section{Introduction}

Complementary to bottom-up methodologies for deriving emissions estimates, inverse modeling has the potential to improve those estimates through the use of atmospheric observations of trace gas compounds, in particular over regions undergoing fast economic development and facing intense air pollution problems, like eastern China (Worden et al., 2012; Reuter et al., 2014; Mijling and van der A, 2012; Ding et al., 2015) but also on the global scale (Jaeglé et al., 2005; Chang and Song, 2010; Kopacz et al., 2010). Pollutants like CO and $\mathrm{NO}_{2}$ are directly detected from satellite and their emissions have been inferred using inversion techniques on different scales (e.g., Pétron et al., 2004; Müller and Stavrakou, 2005; Stavrakou et al., 2008; Kopacz et al., 2010; Tang et al., 2013). The detection of formaldehyde columns from satellite sensors measuring in the UV-visible spectral window opened the way for the derivation of fluxes of non-methane volatile organic compounds (NMVOCs), a broad class of formaldehyde precursors emitted by vegetation, fires, and anthropogenic activities (Chance et al., 2000; Palmer et al., 2003, 2006). These compounds have a profound impact on air quality and climate, owing to their influence on $\mathrm{OH}$ levels and the methane lifetime and to their role as precursors of ozone and secondary organic aerosols (Hartmann et al., 2013). The accurate estimation of their fluxes is therefore of utmost importance.

Natural emission from vegetation is the dominant volatile organic compound (VOC) source. The global annual flux is estimated at ca. $1000 \mathrm{Tg} \mathrm{VOC}$, with isoprene accounting for half of this emission (Guenther et al., 1995, 2012; Sindelarova et al., 2014). Despite a general consensus on the isoprene emission patterns, including their dependence on temperature and light density responsible for their marked diurnal and seasonal variations, these emission estimates come, however, with large uncertainties, associated with the strong variability of emission factors and the extrapolation of sparse measurements to larger scales. An uncertainty of a factor of 2 in global and regional isoprene fluxes was reported based on a compilation of numerous literature studies (Sindelarova et al., 2014), whereas emission models were found to be strongly sensitive to choices of input variables, leading to even wider uncertainty, of ca. $200-1000 \mathrm{Tg}$ C year ${ }^{-1}$ globally (Arneth et al., 2011).

The global biomass burning fluxes are estimated by bottom-up inventories to be ca. $1300-2200 \mathrm{Tg} \mathrm{C}$ on a yearly basis, which corresponds to $40-100 \mathrm{Tg} \mathrm{VOC}_{\text {year }}{ }^{-1}$ using emission factors from the compilation of Andreae and Merlet (2001) or Akagi et al. (2011) (van der Werf et al., 2010; Wiedinmyer et al., 2011). These estimates, however, depend on assumptions made in fire emission models regarding fuel loading and consumption efficiency and on the quality of land cover maps and fire proxies from satellite (Hyer and Reid, 2009; Wiedinmyer et al., 2011; Soares et al., 2015).

Formaldehyde is a high-yield product in the oxidation of a large majority of NMVOCs. Isoprene alone is responsible for approximately $30 \%$ of the global HCHO burden according to model estimates (Stavrakou et al., 2009b), whereas the contribution of vegetation fires is globally small (3\%) but can be locally very important. Spaceborne vertical columns of $\mathrm{HCHO}$ retrieved from GOME, SCIAMACHY, the Ozone Monitoring Instrument (OMI), and GOME-2 sensors have been used to constrain the VOC budget on different scales (e.g., Palmer et al., 2003, 2006; Millet et al., 2008; Barkley et al., 2013; Bauwens et al., 2014; Zhu et al., 2014). Topdown flux estimates deduced from two satellite sensors with different overpass times showed a good degree of consistency over the Amazon (Barkley et al., 2013) and globally (Stavrakou et al., 2015). The latter study using GOME-2 (09:30 LT) and OMI (13:30 LT) HCHO observations in 2010 reported a good agreement between the inversion results over most areas and identified large regions where the derived emissions were highly consistent (e.g., Amazonia, southeastern US). Encouraged by those results, and relying on a multiyear record of HCHO columns observed by the OMI sensor, we use inverse modeling to derive top-down pyrogenic and biogenic VOC estimates over 2005-2013. The satellite data offer an unparalleled opportunity to bring new insights in our understanding of emissions and their quantification, to infer long-term seasonal and interannual flux variability, and to detect potential emission trends that may not be well represented in bottom-up inventories. To this purpose, we use a global chemistry-transport model (CTM), coupled with an inversion module and a minimization algorithm adjusting the emissions used in the model, in order to achieve an optimal match between the modeled and the observed HCHO columns while accounting for errors in the a priori emissions and the HCHO observations. The optimized fluxes are compared with independent bottom-up pyrogenic and biogenic emission inventories as well as with previous literature studies. The methodology is briefly presented in Sect. 2, and an overview of the results is discussed in Sect. 3. The topdown fluxes and comparisons to bottom-up inventories over big world regions are discussed thoroughly in Sects. 4-8 and emission trends in Sect. 9. Conclusions and final remarks are presented in Sect. 10. 


\section{Methods}

We used formaldehyde observations retrieved from the OMI spectrometer aboard the Aura mission and fully documented in a recent study (De Smedt et al., 2015). The retrievals are based on an improved DOAS algorithm that reduces the effect of interferences between species and ensures maximum consistency between the OMI and GOME-2 columns. The current data version (v14) uses an iterative algorithm to remove spikes in the residuals of the slant columns and a procedure based on the background normalization to remove striping artifacts due to calibration problems (Boersma et al., 2011; Richter et al., 2011; De Smedt et al., 2015). In addition to the destriping procedure, in order to reduce the effect of the OMI row anomaly issue affecting the spectra after 2007 (http://www.knmi.nl/omi/research/ product/rowanomaly-background.php), the OMI rows presenting higher levels of noise and fitting residuals than the average were systematically removed from the dataset (De Smedt et al., 2015). Although this filtering leads to a loss of coverage, the resulting dataset is more appropriate for addressing trend studies, as explained in De Smedt et al. (2015).

The IMAGESv2 global model calculates the concentrations of 131 transported and 41 short-lived trace gases with a time step of $6 \mathrm{~h}$ at $2^{\circ} \times 2.5^{\circ}$ resolution between the surface and the lower stratosphere. The effect of diurnal variations is accounted for through correction factors on the photolysis and kinetic rates obtained from model simulations with a time step of $20 \mathrm{~min}$, which are also used to calculate the diurnal shapes of formaldehyde columns required for the comparison with satellite data. A detailed model description is provided in Stavrakou et al. (2013). Meteorological fields are obtained from ERA-Interim analyses of the European Centre for Medium-range Weather Forecasts (ECMWF). The model uses anthropogenic $\mathrm{NO}_{x}, \mathrm{CO}, \mathrm{SO}_{2}$, $\mathrm{NH}_{3}$, and total NMVOC emissions from the Emission Database for Global Atmospheric Research (EDGAR4.2, http://edgar.jrc.ec.europa.eu), which is overwritten by the EMEP inventory (http://www.ceip.at/ms) over Europe and by the REASv2 inventory (Kurokawa et al., 2013) over Asia. The NMVOC speciation is obtained from REASv2 over Asia and from the RETRO inventory (Schultz et al., 2007) elsewhere. The emissions over the US are scaled according to the NEI national totals for all years between 2005 and 2013 (http://www.epa.gov/air-emissions-inventories/ air-pollutant-emissions-trends-data).

Biomass burning emissions are taken from the latest version of the Global Fire Emissions Database, GFED4s (July 2015), which includes the contribution of small fires based on active fire detections (Randerson et al., 2012; Giglio et al., 2013). The GFED data are available on a daily basis at $0.25^{\circ} \times 0.25^{\circ}$ resolution from 1997 through the present at http://www.globalfiredata.org. Those emissions are distributed vertically according to Sofiev et al. (2013).
A priori isoprene emissions are obtained from the MEGAN-MOHYCAN model (Müller et al., 2008; Stavrakou et al., 2014) for all years of the study period at a resolution of $0.5^{\circ} \times 0.5^{\circ}$ (http://tropo.aeronomie.be/models/isoprene. $\mathrm{htm})$. Besides the emission dependence on leaf temperature, photosynthetically active radiation (PAR), leaf area, and leaf age, the model accounts for the inhibition of isoprene emissions in very dry soil conditions through a dimensionless soil moisture activity factor $\left(\gamma_{\mathrm{SM}}\right)$ expressed as a function of volumetric soil moisture content (Guenther et al., 2006) obtained from the ERA-Interim reanalysis. The parameterization of $\gamma_{\mathrm{SM}}$ bears large uncertainties, as it is based on scarce (and sometimes contradictory) field data, and its implementation can lead to very different results depending on the choice of database for soil moisture data (Müller et al., 2008; Sindelarova et al., 2014; Marais et al., 2012). It reduces the emissions by ca. $20 \%$ globally according to MEGANMOHYCAN, with strongest effects (up to factor of 3 or more) over Australia and southern Africa and to a lesser extent over northern Africa (Sahel), the western US, and the Middle East.

The chemical degradation mechanism of pyrogenic NMVOCs is largely described in Stavrakou et al. (2009a), with only minor modifications. This mechanism includes an explicit treatment for 16 pyrogenic formaldehyde precursors. The emissions of other pyrogenic compounds is represented through a lumped compound (OTHC) with a simplified oxidation mechanism designed in order to reproduce the overall formaldehyde yield of the explicit NMVOC mix it represents. The oxidation mechanism for isoprene is based on Stavrakou et al. (2010), modified to account for the revised kinetics of isoprene peroxy radicals according to the Leuven Isoprene Mechanism version 1 (LIM1) (Peeters et al., 2014), as well as for the chemistry of the isoprene epoxides (IEPOX) following the Master Chemical Mechanism (MCMv3.2; http://mcm.leeds.ac.uk/ MCMv3.2/). Using a box model, the formaldehyde yield in isoprene oxidation by $\mathrm{OH}$ is calculated to be $2.4 \mathrm{~mol} \mathrm{~mol}^{-1}$ in high $\mathrm{NO}_{x}\left(1\right.$ ppbv $\mathrm{NO}_{2}$, after 2 months of simulation) and $1.9 \mathrm{~mol} \mathrm{~mol}^{-1}$ for $0.1 \mathrm{ppbvNO} \mathrm{NO}_{2}$. It should be stressed that the isoprene mechanism still bears important uncertainties at low- $\mathrm{NO}_{x}$ conditions, as both the oxidation products of the isoprene epoxides and the isomerization products of isoprene peroxy radicals have complex degradation mechanisms that are still far from being well elucidated despite recent progress (Peeters et al., 2014; Bates et al., 2016). Note that suppressing the isomerization channel in the isoprene degradation resulted in only slightly higher model HCHO columns over isoprene-rich regions (Stavrakou et al., 2015).

The mismatch between the CTM and the observations, quantified by the cost function $J$,

$$
J(f)=\frac{1}{2}\left((H(\boldsymbol{f})-\boldsymbol{y})^{\mathrm{T}} \mathbf{E}^{-1}(H(\boldsymbol{f})-\boldsymbol{y})+\boldsymbol{f}^{\mathrm{T}} \mathbf{B}^{-1} \boldsymbol{f}\right),
$$



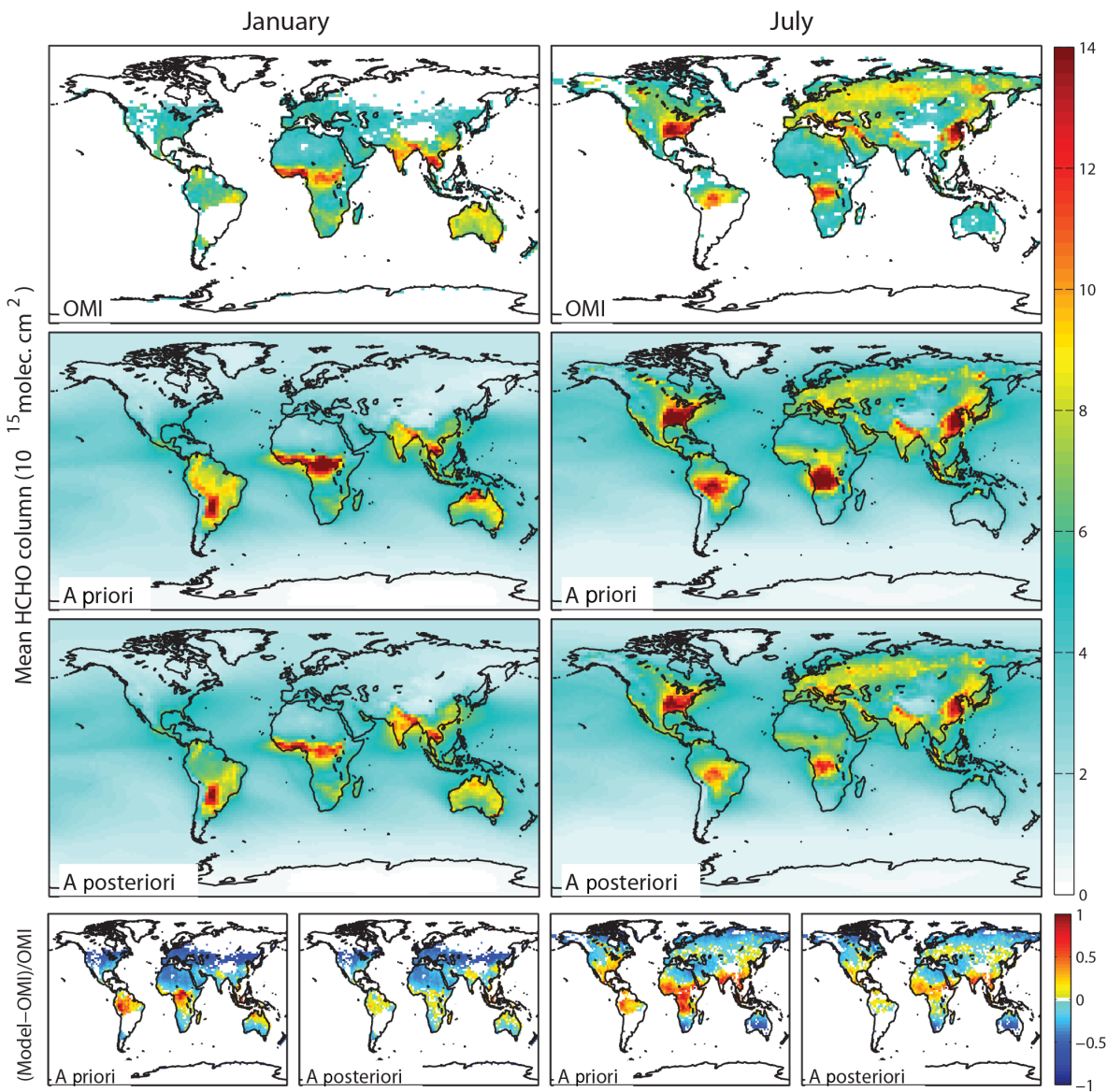

Figure 1. Global distributions of mean 2005-2013 HCHO columns for January and June observed by OMI (upper panels), modeled using emissions (middle panels) and inferred after optimization (lower panels). The columns are expressed in $10^{15}$ molec. $\mathrm{cm}^{-2}$. The observed monthly averages exclude scenes with cloud fractions higher than $40 \%$ and land fractions lower than $20 \%$, as well as data with a retrieval error higher than $100 \%$. The four lower panels illustrate the model-data difference before and after optimization for January and July.

is minimized through an iterative quasi-Newton optimization algorithm, which is based on the calculation of the partial derivatives of $J$ with respect to the input variables. In our case the input variables are scalars $\boldsymbol{f}=\left(f_{j}\right)$, such that the optimized flux can be expressed as

$\Phi_{i}^{\mathrm{opt}}(x, t)=\sum_{j=1}^{m} e^{f_{j}} \Phi_{i}(x, t)$,

with $\Phi_{i}(x, t)$ being the initial flux depending on space (latitude, longitude) and time (month) and $m$ being the emission categories or processes. In Eq. (1), $H(f)$ denotes the model acting on the variables, $\boldsymbol{y}$ the observation vector, $\mathbf{E}$ and $\mathbf{B}$ the covariance matrices of the errors in the observations and on the a priori parameters $\boldsymbol{f}$, respectively, and ${ }^{\mathrm{T}}$ means the transpose of the matrix. The partial derivatives of $J$ with respect to $f$ are calculated by the discrete adjoint of the IMAGESv2 chemistry-transport model (CTM) (Müller and Stavrakou, 2005; Stavrakou et al., 2009b). The derivation of monthly pyrogenic and biogenic fluxes is carried out on a global scale at the resolution of the model $\left(2^{\circ} \times 2.5^{\circ}\right)$, as described in detail in Stavrakou et al. (2015). The inversions are performed separately for all years of the study period (20052013), and about 60000 flux parameters are optimized per year globally.

The covariance matrix of the observational errors is assumed to be diagonal. The errors are calculated as the squared sum of the retrieval error and a representativity error set to $2 \times 10^{15}$ molec. $\mathrm{cm}^{-2}$. The assumed error in the a priori biogenic and pyrogenic fluxes is factor of 3 . This choice reflects the high variability of the biomass burning emission source and the strong uncertainties associated with the biogenic emissions, as demonstrated by the large range of literature emission estimates (Arneth et al., 2011; Sindelarova et al., 2014). The spatiotemporal correlations among the a priori errors in the flux parameters are defined as in Stavrakou et al. (2009b). About 20-40 iterations are needed to reach convergence, which is attained when the gradient of the cost function is reduced by a factor of 1000 with respect 

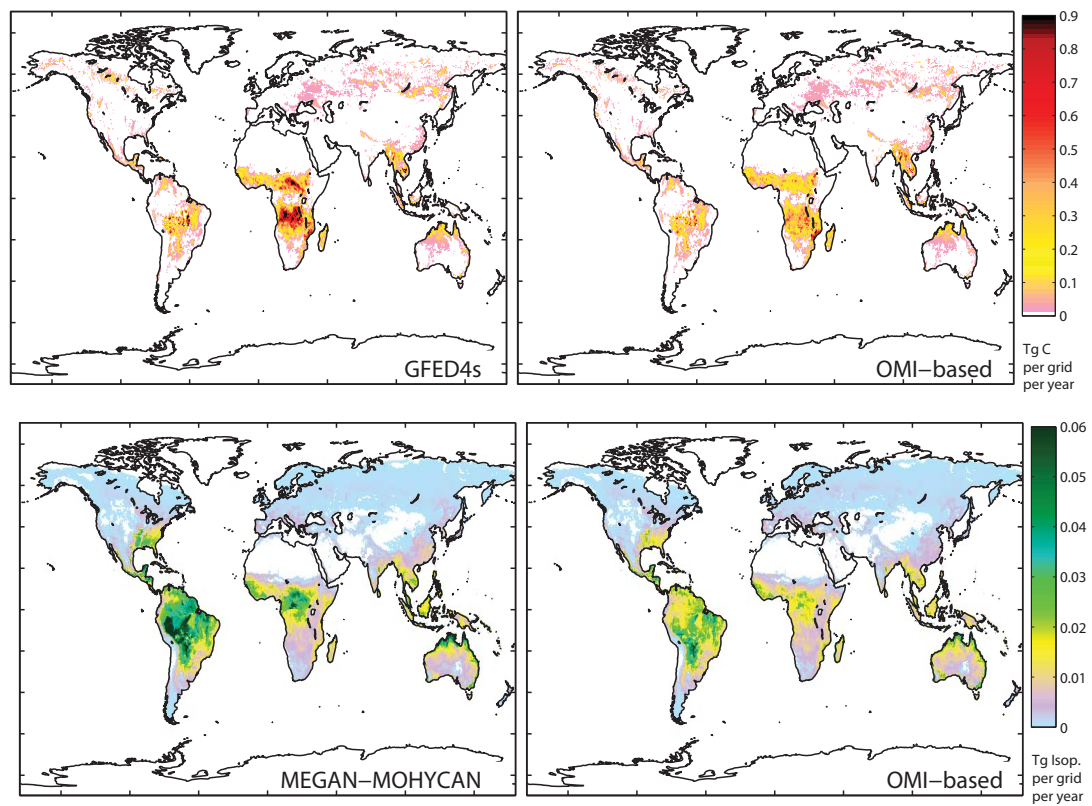

Figure 2. Upper panel: mean (2005-2013) annual biomass burning emission estimates in Tg C/grid per year according to the a priori inventory GFED4s and to the OMI-based biomass burning emissions. Lower panel: mean (2005-2013) annual isoprene emission estimates in Tg isoprene per grid cell per year according to the a priori MEGAN-MOHYCAN inventory and from the OMI-based inversion.

to its initial value. The cost function generally decreases by ca. $45-55 \%$ in comparison to its initial value.

Figure 1 illustrates a comparison between observed monthly mean HCHO column densities over 2005-2013 and monthly columns simulated by the IMAGESv 2 model sampled at the time and location of the satellite measurement. The observed monthly averages exclude scenes with cloud fractions higher than $40 \%$ and land fractions lower than $20 \%$, as well as data with a retrieval error higher than $100 \%$. The number of effective observational constraints is highest in the first years of the OMI mission (ca. 17000 per year) and declines by about $15 \%$ after 2009 due to instrumental degradation effects (De Smedt et al., 2015), whereas the data availability is higher during the summer than in the winter in the Northern Hemisphere (ca. 1600 vs. 1200 measurements per month). The satellite columns are freely available at the BIRA-IASB website (http://h2co.aeronomie.be). The OMIbased emission fluxes presented in this study are available at the GlobEmission web portal (http://www.globemission.eu).

\section{Overview of the results}

The source optimization leads to a good overall agreement with the OMI observations (Fig. 1), in particular in the tropics, as a result of the high signal-to-noise ratio in the observations at these latitudes. The a posteriori columns remain close to the a priori at high latitudes, mainly due to lower data availability and higher observational errors at these latitudes (De Smedt et al., 2015). The inferred mean HCHO columns over the study period are generally decreased by $20-25 \%$ over the Amazon and equatorial Africa, whereas a mean decrease of about $13 \%$ is found in the southeastern US during summertime (cf. Supplement, Fig. S1). The HCHO columns are increased in a few regions after inversion, especially during biomass burning events. The annually averaged global distribution of pyrogenic and isoprene emissions over 20052013 before and after optimization is illustrated in Fig. 2. Figure 3 displays the extent of the regions over which comparisons will be discussed. Bottom-up and top-down emission estimates are summarized in Tables 1 and 2.

The OMI-based fire flux estimates are compared with two independent inventories: GFAS and FINNv1.5. The Global Fire Assimilation System (GFAS) is based on the assimilation of fire radiative power observed from the MODIS instruments aboard the Terra and Aqua satellites (Kaiser et al., 2012) and provides daily global fire emission estimates at $0.5^{\circ} \times 0.5^{\circ}$ and $0.1^{\circ} \times 0.1^{\circ}$ resolution for 2003 onwards (http://eccad.sedoo.fr). The Fire Inventory from NCAR (FINN) version 1.5 is an updated version of the FINN daily global high-resolution inventory (Wiedinmyer et al., 2011). In addition to GFED4s, we also used GFED4. Both version have adopted lower fuel consumption rates than the previous version GFED3 (van der Werf et al., 2010) to better match field observations (van Leeuwen et al., 2014), but in GFED4s this decrease is compensated for by the addition of small (s) fire-burned area. It is available at http://www. globalfiredata.org. The average 2005-2013 global burned biomass is estimated at 1938, 2006, and $1438 \mathrm{Tg} \mathrm{C}$ year $^{-1}$ 
Table 1. Mean a priori and OMI-based emission estimates compared to independent emission inventories for open biomass burning and isoprene emissions calculated for different world regions and globally. Regions are defined in Fig. 3. The means are taken over the period of data availability, i.e., over 2005-2013 for all inventories, except for MEGAN-MACC (2005-2010) and GUESS-ES (2005-2009). NH: Northern Hemisphere; SH: Southern Hemisphere.

\begin{tabular}{|c|c|c|c|c|c|c|c|c|c|}
\hline & $\begin{array}{r}\text { North } \\
\text { America }\end{array}$ & $\begin{array}{r}\text { South } \\
\text { America }\end{array}$ & Europe & $\begin{array}{r}\mathrm{NH} \\
\text { Africa }\end{array}$ & $\begin{array}{r}\mathrm{SH} \\
\text { Africa }\end{array}$ & Russia & $\begin{array}{r}\text { Southeast } \\
\text { Asia }\end{array}$ & Australia & Global \\
\hline \multicolumn{10}{|c|}{ Biomass burning emissions (burned biomass in $\mathrm{Tg} \mathrm{C}$ year $^{-1}$ ) } \\
\hline GFED4s & 105 & 319 & 31 & 418 & 684 & 130 & 237 & 104 & 2028 \\
\hline OMI-based & 86 & 273 & 35 & 320 & 530 & 112 & 203 & 95 & 1653 \\
\hline GFAS & 187 & 328 & 22 & 333 & 431 & 264 & 246 & 126 & 1938 \\
\hline FINNv1.5 & 112 & 452 & 34 & 278 & 415 & 114 & 579 & 22 & 2006 \\
\hline GFED4 & 84 & 231 & 17 & 279 & 479 & 97 & 156 & 95 & 1438 \\
\hline \multicolumn{10}{|c|}{ Isoprene emissions ( $\mathrm{Tg}$ isoprene year ${ }^{-1}$ ) } \\
\hline MEGAN MOHYCAN & 32 & 141 & 6.8 & 50 & 29 & 9.4 & 36 & 38 & 343 \\
\hline OMI-based & 26 & 97 & 8.4 & 35 & 28 & 11 & 31 & 36 & 272 \\
\hline MEGAN-MACC & 34 & 173 & 7.8 & 103 & 67 & 12 & 80 & 94 & 570 \\
\hline GUESS-ES & 44 & 143 & 18.1 & 77 & 60 & 20 & 63 & 26 & 452 \\
\hline
\end{tabular}

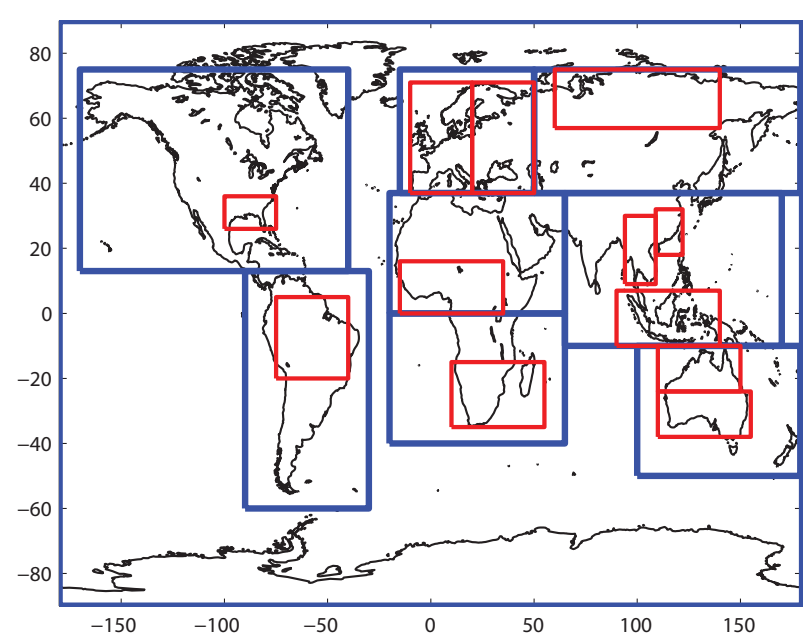

Figure 3. Definition of big and small regions used in this study. Big regions are $\mathrm{N}$ America $\left(13-75^{\circ} \mathrm{N}, 40-170^{\circ} \mathrm{W}\right)$, S America $\left(60^{\circ} \mathrm{S}-\right.$ $\left.13^{\circ} \mathrm{N}, 90^{\circ} \mathrm{W}-30^{\circ} \mathrm{E}\right)$, Europe $\left(37-75^{\circ} \mathrm{N}, 15^{\circ} \mathrm{W}-50^{\circ} \mathrm{E}\right), \mathrm{NH}$ Africa $\left(0-37^{\circ} \mathrm{N}, 20^{\circ} \mathrm{W}-65^{\circ} \mathrm{E}\right)$, SH Africa $\left(0-40^{\circ} \mathrm{S}, 20^{\circ} \mathrm{W}-65^{\circ} \mathrm{E}\right)$, Russia $\left(37-75^{\circ} \mathrm{N}, 50-179^{\circ} \mathrm{E}\right)$, SE Asia $\left(10^{\circ} \mathrm{S}-37^{\circ} \mathrm{N}, 65-170^{\circ} \mathrm{E}\right)$, and Australia $\left(10-50^{\circ} \mathrm{S}, 110-179^{\circ} \mathrm{E}\right)$. Small regions are the SE US $\left(26-36^{\circ} \mathrm{N}, 75-100^{\circ} \mathrm{W}\right)$, Amazonia $\left(5-20^{\circ} \mathrm{S}, 40-75^{\circ} \mathrm{W}\right)$, W Europe $\left(37-71^{\circ} \mathrm{N}, 10^{\circ} \mathrm{W}-20^{\circ} \mathrm{E}\right), \mathrm{E}$ Europe $\left(37-71^{\circ} \mathrm{N}, 20-50^{\circ} \mathrm{E}\right)$, northern Africa $\left(0-16^{\circ} \mathrm{N}, 15^{\circ} \mathrm{W}-35^{\circ} \mathrm{E}\right)$, southern Africa $(15$ $\left.35^{\circ} \mathrm{S}, 10-55^{\circ} \mathrm{E}\right)$, Siberia $\left(57-75^{\circ} \mathrm{N}, 60-140^{\circ} \mathrm{E}\right)$, south China (18$\left.32^{\circ} \mathrm{N}, 109-122^{\circ} \mathrm{E}\right)$, Indochina $\left(9-30^{\circ} \mathrm{N}, 94-109^{\circ} \mathrm{E}\right)$, Indonesia $\left(10^{\circ} \mathrm{S}-7^{\circ} \mathrm{N}, 90-140^{\circ} \mathrm{E}\right), \mathrm{N}$ Australia $\left(10-24^{\circ} \mathrm{S}, 110-150^{\circ} \mathrm{E}\right)$, and S Australia $\left(24-38^{\circ} \mathrm{S}, 110-155^{\circ} \mathrm{E}\right)$.

in GFAS, FINNv1.5 and GFED4, respectively (Table 1; Fig. S2).

The isoprene emission estimates are compared to two bottom-up inventories: MEGAN-MACC and GUESS-ES
Table 2. Global a priori and OMI-based emission estimates per year. Fire estimates are expressed in $\mathrm{Tg} \mathrm{C}_{\mathrm{Cear}}{ }^{-1}$, isoprene in $\mathrm{Tg}$ of isoprene per year.

\begin{tabular}{lrrrr}
\hline Year & $\begin{array}{r}\text { A priori } \\
\text { fires }\end{array}$ & $\begin{array}{r}\text { Optimized } \\
\text { fires }\end{array}$ & $\begin{array}{r}\text { A priori } \\
\text { isoprene }\end{array}$ & $\begin{array}{r}\text { Optimized } \\
\text { isoprene }\end{array}$ \\
\hline 2005 & 2252 & 1936 & 349 & 282 \\
2006 & 2207 & 1721 & 339 & 280 \\
2007 & 2202 & 1966 & 340 & 285 \\
2008 & 1873 & 1605 & 324 & 263 \\
2009 & 1862 & 1504 & 339 & 269 \\
2010 & 2150 & 1679 & 363 & 272 \\
2011 & 1872 & 1404 & 341 & 258 \\
2012 & 2058 & 1676 & 350 & 276 \\
2013 & 1773 & 1383 & 338 & 265 \\
$2005-2013$ & 2028 & 1653 & 343 & 272 \\
\hline
\end{tabular}

(Fig. S3). MEGAN-MACC (Sindelarova et al., 2014) relies on the MEGANv2.1 model for biogenic volatile organic compounds (BVOC) and is based on the MERRA reanalysis fields (Rienecker et al., 2011). The emissions are provided at $0.5^{\circ} \times 0.5^{\circ}$ resolution and on a monthly basis from 1980 through 2010. The GUESS-ES isoprene inventory is based on the physiological isoprene emission algorithm described by Niinemets et al. (1999) and updated by Arneth et al. (2007). It is coupled to the dynamic global vegetation model LPJ-GUESS (Sitch et al., 2003) and is driven by the CRU (Climatic Research Unit) monthly meteorological fields (Mitchell and Jones, 2005) at $1^{\circ} \times 1^{\circ}$ resolution between 1969 and 2009. Both inventories are available from the ECCAD data portal (http://eccad.sedoo.fr). The mean isoprene emission amounts to 452 and to $570 \mathrm{Tg} \mathrm{year}^{-1}$, according to the GUESS-ES and to the MEGAN-MACC in- 
ventory, respectively (Table 1), and both lie much higher than the a priori MEGAN-MOHYCAN inventory (343 Tg year $^{-1}$ average over 2005-2013). The large discrepancy between MEGAN-MACC and MEGAN-MOHYCAN datasets, both relying on the MEGAN emission model (Guenther et al., 2006) and the same version of basal emission factors (version 2011), can be explained to a large extent by (i) the neglect of soil moisture stress effects in MEGAN-MACC, (ii) a reduction by a factor of 4.1 of the basal emission factors for forests in Asia in MEGAN-MOHYCAN (Stavrakou et al., 2014) as suggested by field observations in Borneo (Langford et al., 2010), and (iii) the use of the crop distribution database of Ramankutty and Foley (1999) in MEGANMOHYCAN, along with the necessary adjustment of the other plant functional type distributions, leading overall to larger crop extent and lower total emissions.

The average global fire flux, expressed as burned biomass, is reduced from $2028 \mathrm{Tg} \mathrm{C}$ year $^{-1}$ (GFED4s) to $1653 \mathrm{Tg}$ $\mathrm{C}_{\text {year }}{ }^{-1}$ after optimization (Table 1$)$. Note that the inversion provides updated VOC emissions of $\mathrm{HCHO}$ precursors. However, to ease the comparison with other inventories, VOC emissions are converted to carbon emissions through the use of emission factors obtained from the compilation of Andreae and Merlet (2001) (with 2011 updates). It should be acknowledged that the top-down estimates given here for fuel consumption may be affected by errors in the emission factors as well as by errors in the formaldehyde yields per VOC. The strongest emission decreases are induced over Africa (23\%), South America, and southeast Asia $(15 \%)$, whereas in Europe the fire fluxes are $12 \%$ higher than in GFED4s. The reduced top-down emission agrees within $15 \%$ with the GFED4 inventory (1438 $\mathrm{Tg} \mathrm{C} \mathrm{year}^{-1}$ ) and is ca. $18 \%$ lower than the GFAS and FINN global estimates. The lower a posteriori emissions in Africa are supported by the independent inventories, and the flux updates in Europe and Russia are in good agreement with the FINN fluxes. At tropical latitudes, the estimates from the independent inventories often exhibit large discrepancies, underscoring the large uncertainty of this source, while the top-down emissions lie generally within their range (Table 1; Fig. 4).

The OMI-based fire emissions present a marked interannual variability, between a minimum of $1383 \mathrm{Tg} \mathrm{C}$ in 2013 and a maximum of $1966 \mathrm{Tg} \mathrm{C}$ in 2007 (Table 2). Figure 4 illustrates the coefficient of variability, defined as the standard deviation of the emissions divided by the mean, which is a measure of the interannual variability of the emissions (Giglio et al., 2013). The GFED4s coefficient is lowest over Africa (less than 0.15) and highest in South America, southeast Asia, Russia, and Australia (0.35-0.57). The low variability over Africa can be explained by the dominance of intense savanna fires that are highly regular throughout the years. According to the source attribution of GFED4s, deforestation fires are by far the prevailing source, responsible for $80 \%$ of the total emission in South America, while the rest is due to savanna burning occurring in northeastern South
America. The coefficient of variation of South American deforestation fires amounts to 0.74 , pointing to the strong effect of climate variability, caused by, e.g., the strong El NiñoSouthern Oscillation (ENSO), on the fire occurrence in the Amazon (Alencar et al., 2011), and the rapid decline in deforestation rates over 2005-2013 (Nepstad et al., 2014). In addition, the estimated coefficient for savanna fires $(0.41)$ is substantially higher than for the African savannas due to the strong variability of fire burning in northern South America (Romero-Ruiz et al., 2010). In Australia, savanna, grassland, and shrubland fires are responsible for the high interannual variability of the GFED4s inventory (0.42). In southeast Asia the contribution of peat burning to the total fire flux varies strongly from year to year $(0-38 \%)$ and drives the high coefficient of variability (0.45) (Giglio et al., 2013). After inversion, the coefficient of variability is reinforced over Europe and Southern Hemisphere ( $\mathrm{SH})$ Africa but is reduced in the tropics, especially over southeast Asia and South America, where the decreased top-down variability is supported by comparisons with GFAS and FINN (Fig. 4). This interannual variability of the optimized fluxes will be thoroughly discussed in the following sections (Sects. 4-8).

The global mean 2005-2013 isoprene emission is reduced from 343 to $272 \mathrm{Tg}_{\text {year }}{ }^{-1}$ after inversion (Table 1), with the largest reductions inferred in Northern Hemisphere (NH) Africa and South America (ca. 30\%) and in the southeastern US $(35 \%)$. In contrast to the emission decrease suggested by satellite, the isoprene fluxes estimated by MEGAN-MACC and GUESS-ES are substantially higher, by 100 and $66 \%$, respectively. The interannual variation of the isoprene fluxes is low in all regions, with the coefficient of variability close to 0.04 in the tropics and up to 0.07 in extratropical regions. The satellite columns suggest stronger interannual variability over all regions, except in South America where it is slightly reduced. The interannual variation of isoprene fluxes is low for all inventories, generally stronger in MEGAN-MACC (up to 0.1 ) and weaker in GUESS-ES (Fig. 4).

The monthly variation of the a priori and the OMIbased emissions is compared directly to MODIS Aqua (MYD14CM, 13:30 LT) fire counts (http://reverb.echo.nasa. gov) over 12 smaller regions selected based on literature evidence for the occurrence of small fires (Table 3; Fig. S4). Higher spatial and temporal correlations are calculated after the inversion in all selected areas, especially over agricultural regions, like the southeastern US, eastern Australia, and Maranhão, where the correlation improves significantly from 0.36 to 0.65 , from 0.55 to 0.86 , and from 0.56 to 0.91 , respectively. This shows that satellite $\mathrm{HCHO}$ observations do detect the contribution of small fires. It also explains the improved correlation of OMI-based emissions with GFAS and FINN in South America, northern Africa, and southeast Asia, regions where this contribution is important (Chen et al., 2013; Huang et al., 2012; Karki, 2002; Magi et al., 2012).

The ratio of the optimized to the a priori annual fluxes for biomass burning and isoprene emissions is presented in 

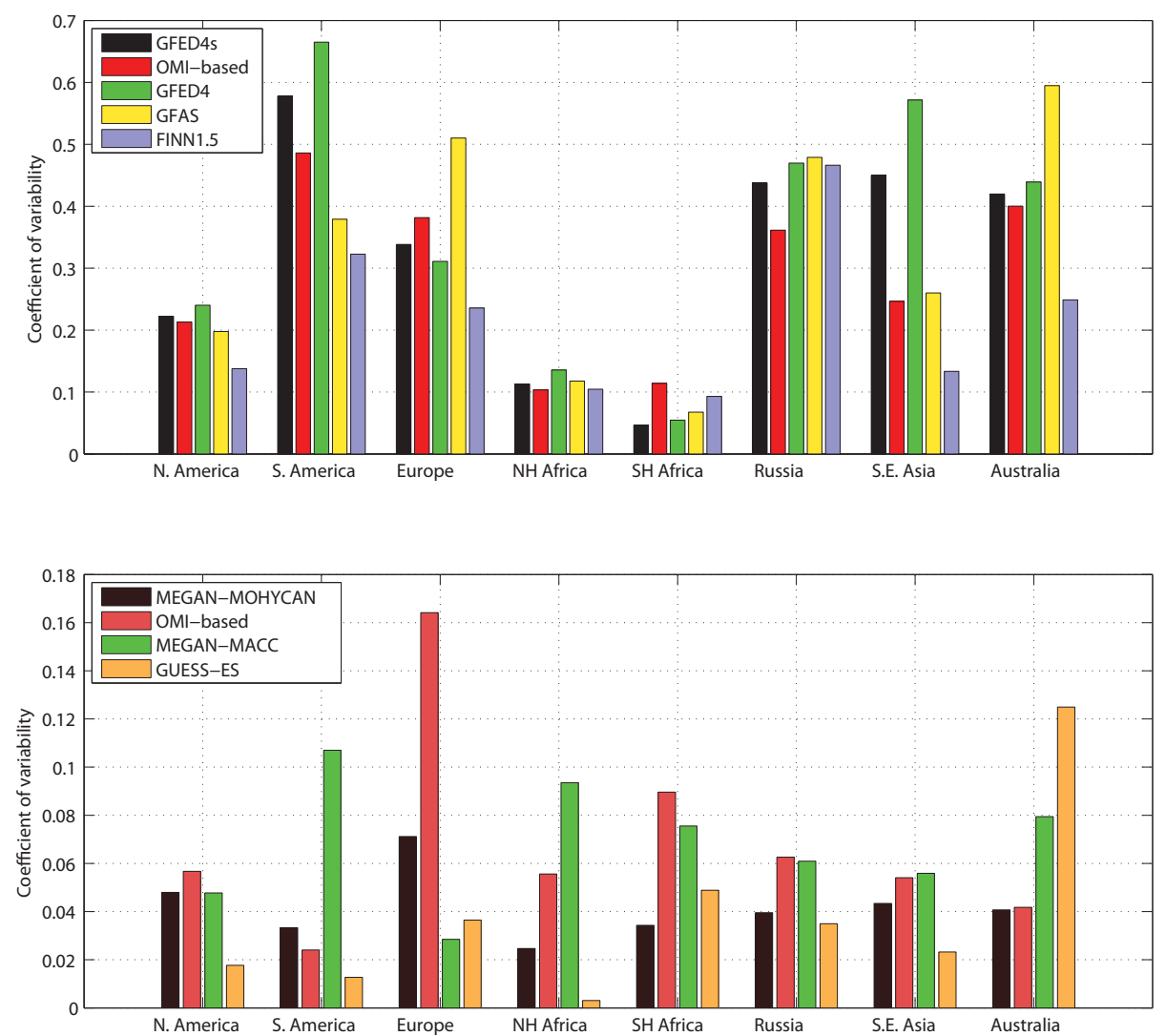

Figure 4. Interannual variability expressed as coefficient of variation, defined as the standard deviation of the emissions divided by the mean of the emissions, given for the a priori, for the OMI-based emission estimates, and for the independent emission inventories of biomass burning (upper panel), and isoprene emissions (lower panel) over the big regions defined in Fig. 3.

Table 3. Temporal correlation between monthly MODIS fire counts, GFED4s, and OMI-based fluxes over the regions selected based on literature evidence for the occurrence of small fires. The regions are shown on the MODIS land cover map in Fig. S4.

\begin{tabular}{lllrr}
\hline Region & Coordinates & Fire type & MODIS vs. GFED4s & MODIS vs. OMI-based \\
\hline N Africa & $4-16^{\circ} \mathrm{N}, 15^{\circ} \mathrm{W}-15^{\circ} \mathrm{E}$ & agricultural $^{\mathrm{a}}$ & 0.89 & 0.96 \\
Maranhão & $6^{\circ} \mathrm{S}-2^{\circ} \mathrm{N}, 44-52^{\circ} \mathrm{W}$ & agricultural $^{\mathrm{a}}$ & 0.56 & 0.91 \\
Mato Grosso & $7-15^{\circ} \mathrm{S}, 50-60^{\circ} \mathrm{W}$ & small-scale deforestation $^{\mathrm{b}}$ & 0.95 & 0.97 \\
SE US & $30-36^{\circ} \mathrm{N}, 75-100^{\circ} \mathrm{W}$ & agricultural $^{\mathrm{a}}$ & 0.36 & 0.65 \\
N China & $30-40^{\circ} \mathrm{N}, 111-122^{\circ} \mathrm{E}$ & agricultural $^{\mathrm{a}}$ & 0.66 & 0.85 \\
Indochina & $6-27^{\circ} \mathrm{N}, 87-110^{\circ} \mathrm{E}$ & agricultural $^{\mathrm{a}}$ and small- $^{\mathrm{a}}$ & & 0.84 \\
& & scale deforestation $^{\mathrm{d}}$ & 0.85 & 0.89 \\
Indonesia & $10^{\circ} \mathrm{S}-5^{\circ} \mathrm{N}, 93-130^{\circ} \mathrm{E}$ & agricultural $^{\mathrm{a}}$ and peat $^{\mathrm{c}}$ & 0.75 & 0.87 \\
NW India & $29-33^{\circ} \mathrm{N}, 70-79^{\circ} \mathrm{E}$ & agricultural fires $^{\mathrm{a}}$ & 0.81 & 0.94 \\
Russia & $52-60^{\circ} \mathrm{N}, 55-90^{\circ} \mathrm{W}$ & agricultural $^{\mathrm{a}}$ and peat $^{\mathrm{c}}$ & 0.96 & 0.99 \\
Eq. Africa & $14^{\circ} \mathrm{S}-2^{\circ} \mathrm{N}, 10-25^{\circ} \mathrm{E}$ & agricultural $^{\mathrm{e}}$ & 0.55 & 0.86 \\
E Australia & $20-40^{\circ} \mathrm{S}, 145-155^{\circ} \mathrm{E}$ & agricultural $^{\mathrm{e}}$ & 0.90 & 0.96 \\
Madagascar & $12-26^{\circ} \mathrm{S}, 43-50^{\circ} \mathrm{E}$ & agricultural $^{\mathrm{e}}$ & & \\
\hline
\end{tabular}

${ }^{a}$ Region dominated by cropland according to the MODIS land cover change (Justice et al., 2002). ${ }^{\mathrm{b}}$ Region with a high number of small deforestation fires (Chen et al., 2013). ${ }^{\mathrm{c}}$ Region with peat fires selected based on Andela et al. (2013). ${ }^{\mathrm{d}}$ Region with a high number of small deforestation fires (Karki, 2002).

${ }^{\mathrm{e}}$ Region where GFED4s emissions are predominantly associated with small fires (Randerson et al., 2012). 

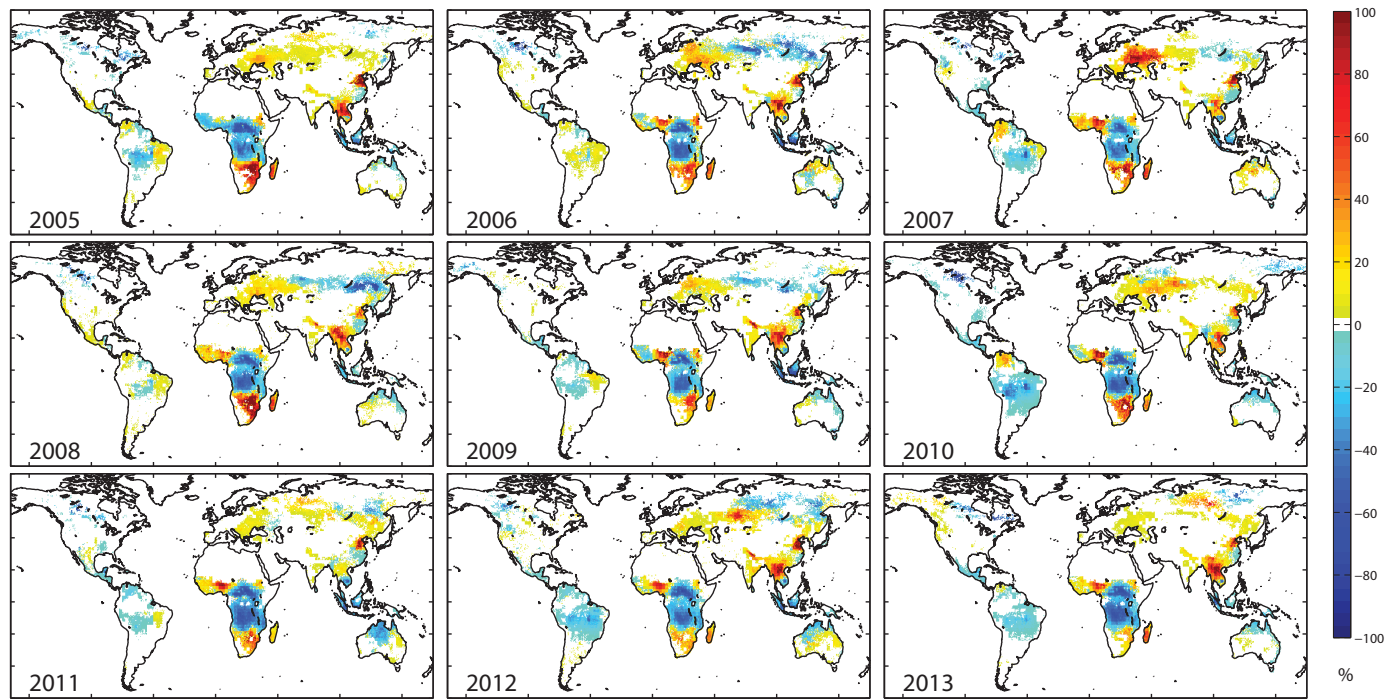

Figure 5. Updates (percentage change from the a priori) in annually averaged biomass burning emissions suggested by the flux inversion for all years of the study period.
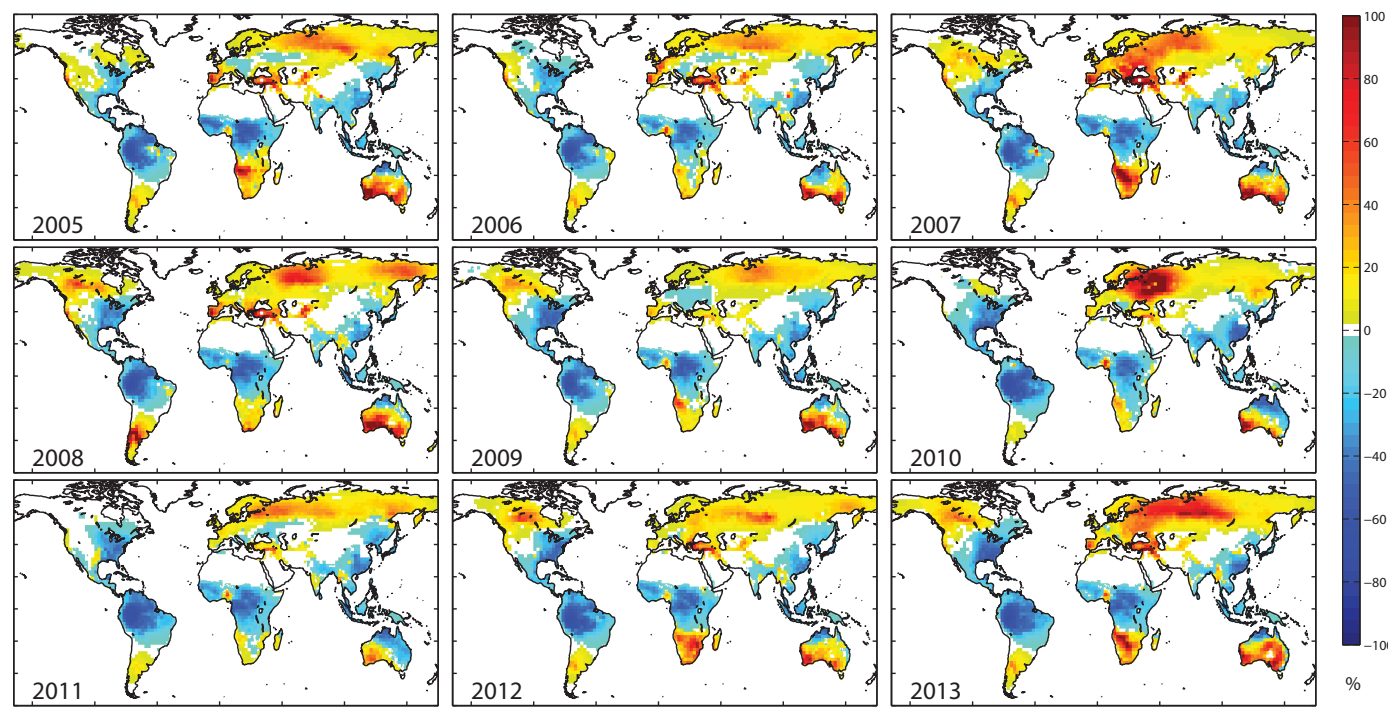

Figure 6. Updates (percentage change from the a priori) in annually averaged isoprene emissions inferred by the optimization for all years of the study period.

Figs. 5 and 6, respectively. The interannual flux variation is displayed in Figs. 7 and 8, and the seasonal variation of the fluxes over different regions (Sects. 4-8) is shown in Figs. 9 and $11-15$. We present detailed results for regions where the satellite observations suggest important changes relative to the a priori fluxes.

\section{Amazonian emissions}

The OMI columns suggest important fire flux decreases during years with strong a priori fluxes, by $16 \%$ in $2005,22 \%$ in 2007 , and $32 \%$ in 2010. The inferred flux reduction in 2010 is corroborated by earlier inversion studies constrained by GOME-2 HCHO columns (Stavrakou et al., 2015), MOPITT CO observations (Bloom et al., 2015), and a multisensorbased emission estimate above Mato Grosso (Anderson et al., 2015). The top-down interannual fire variability is marked but less pronounced compared to the a priori, with the lowest emission inferred in 2009 (80.2 Tg C) and the highest in 2007 (387.4 Tg C; Fig. 7), and it is corroborated by the GFAS and FINN inventories (Fig. 4). The time and duration of the fire season is not modified by the optimization (Fig. 9). The OMI-derived fluxes display the same pronounced seasonality as GFED4s, with fire emissions peaking between August and 

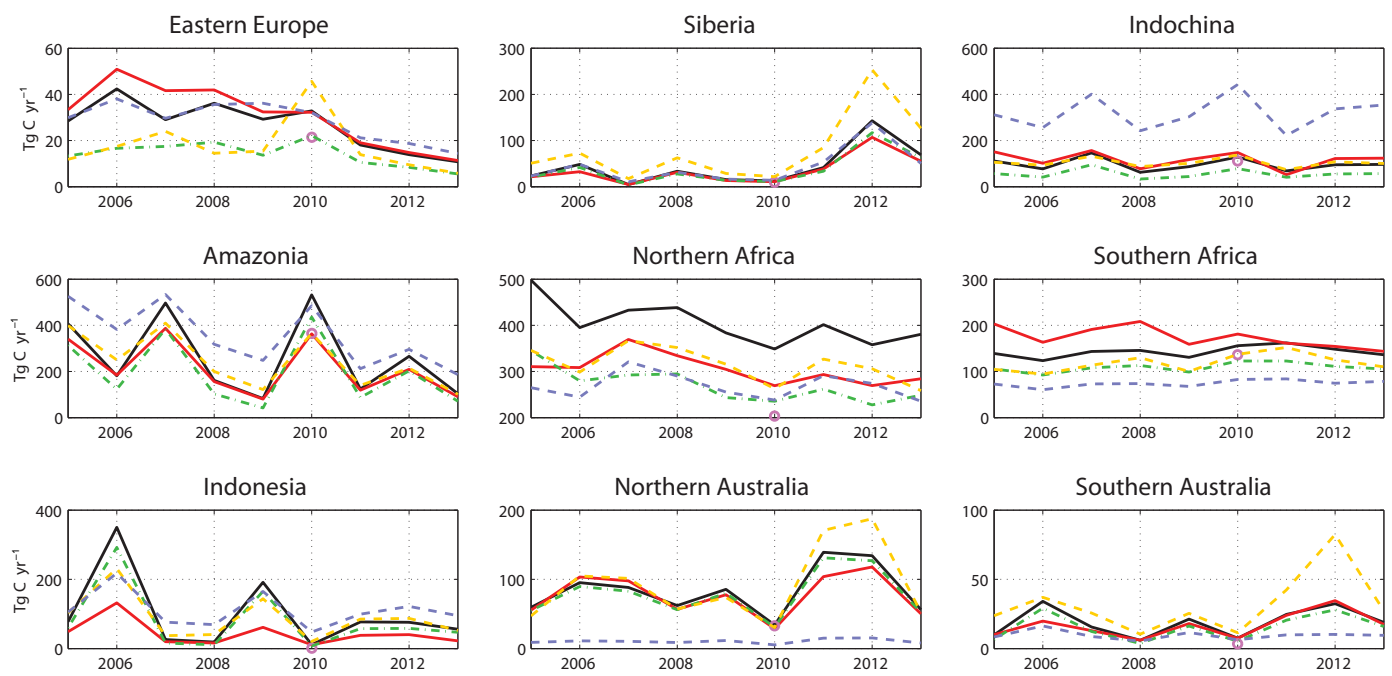

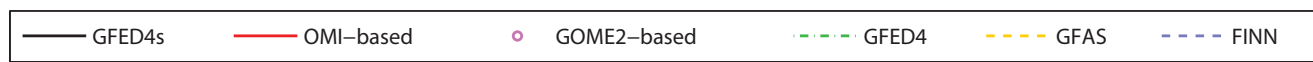

Figure 7. Interannual variation of burned biomass (in $\mathrm{Tg} \mathrm{C}_{\mathrm{Cear}}{ }^{-1}$ ) over 2005-2013 from the a priori inventory (black), the satellite-based estimates (OMI in red), and from other bottom-up inventories (GFED4 in green, GFAS in orange, FINN in blue) over small regions defined in Fig. 3. Units are $\mathrm{Tg} \mathrm{C}_{\mathrm{Cear}}{ }^{-1}$. The GOME-2-inferred estimate is shown as magenta circle.
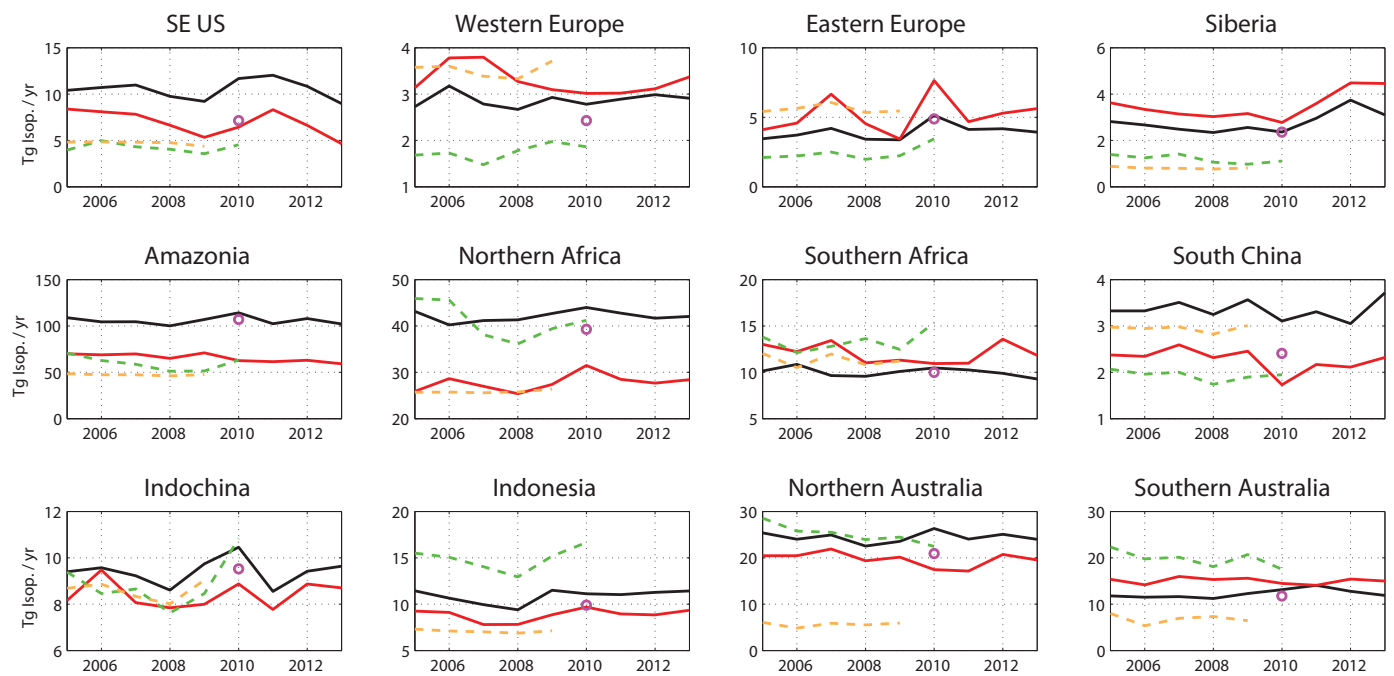

-MEGAN-MOHYCAN $\quad$ OMI-based $\quad \circ$ GOME2-based $\quad---0.5 \times$ MEGAN MACC - - $0.5 \times$ GUESS ES

Figure 8. Interannual variation of isoprene fluxes over 2005-2013 from the a priori inventory (black), the satellite-based estimates (OMI in red), MEGAN-MACC (in green), and GUESS-ES (in orange) over regions (red boxes) defined in Fig. 3. Units are Tg of isoprene per month. The GOME-2-inferred estimate is shown as magenta circle.

September and a rapid decline in October and November, as found in previous studies (Barkley et al., 2008; Bloom et al., 2015; Stavrakou et al., 2015). The independent inventories, however, indicate generally higher fluxes than the top-down fluxes from October to January (Fig. 9).

Regarding isoprene, the inversion infers generally lower fluxes than the a priori inventory for all years of the study period, with a $38 \%$ mean annual reduction over 2005-2013, as illustrated in Figs. 6 and 8. The top-down annual isoprene flux ranges between $59 \mathrm{Tg}$ in 2013 and $70 \mathrm{Tg}$ in 2007, and the a priori interannual and seasonal variability is generally preserved after inversion (Figs. 8, 9) and is similar in all inventories, with minimal emissions during the wet-to-dry season transition (April-June) and higher fluxes during the dry 

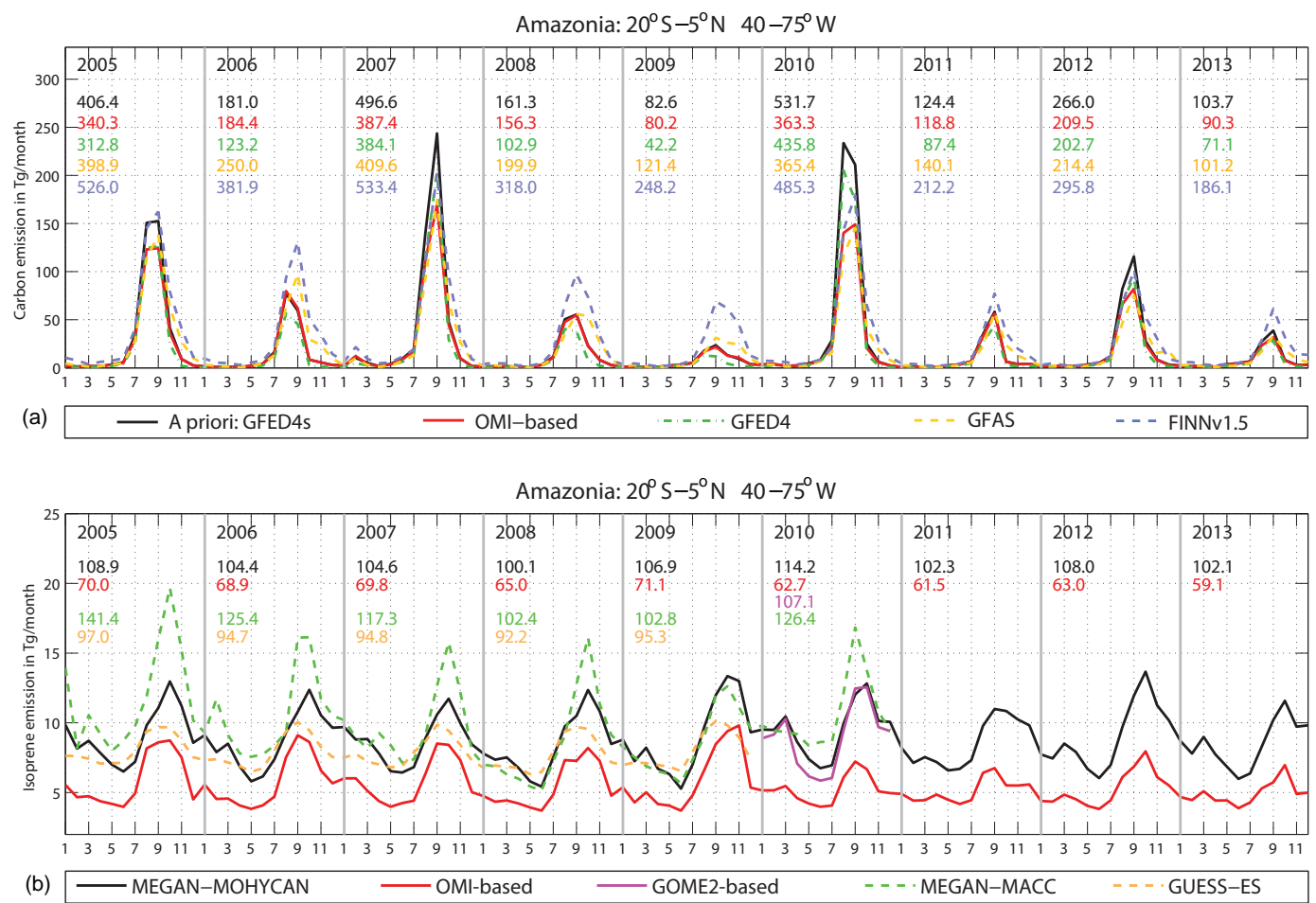

Figure 9. Seasonal and interannual variation of biomass burning emissions and isoprene emissions from bottom-up and top-down estimates over Amazonia (Fig. 3). Units are Tg C per month for biomass burning fluxes and $\mathrm{Tg}$ of isoprene per month for biogenic emissions. The annual emission flux per inventory is given as inset numbers.

season (July-October). The peak-to-trough ratio is about a factor of 2 for the a priori and optimized fluxes, whereas it is weaker in the GUESS-ES inventory (1.6) and stronger in MEGAN-MACC (2.4). During the wet-to-dry transition season (April-June), top-down estimates from GOME-2 and OMI show better consistency than in the dry season (Fig. 9, Stavrakou et al., 2015). An all-year-round emission decrease in most bottom-up inventories was also required in order to reconcile the GEOS-Chem model with SCIAMACHY and OMI HCHO columns (Barkley et al., 2013). The strong seasonal variation and low emissions during the wet-to-dry transition are most likely due new leaf growth and lower flux rates from young leaves (Barkley et al., 2009).

Figure 10 shows a comparison of modeled isoprene fluxes with flux measurements from 12 field campaigns performed in the Amazon. The comparison accounts for the diurnal variations in the fluxes through correction factors used to scale the measured fluxes to daily averages (cf. Table S1). Direct comparisons between modeled fluxes and field measurements should, however, be considered with caution mainly due to the coarse resolution of the modeled emissions but also to the fact that flux measurements were often performed outside the study period (2005-2013). The observed isoprene fluxes exhibit strong local differences within the forest (up to $5 \mathrm{mg} \mathrm{m}^{-2} \mathrm{~h}^{-1}$, Karl et al., 2009), as well as significant differences from one day to another (up to $0.5 \mathrm{mg} \mathrm{m}^{-2} \mathrm{~h}^{-1}$;
Ciccioli et al., 2003; Karl et al., 2007; Kuhn et al., 2007), whereas they may exhibit differences of up to $1 \mathrm{mg} \mathrm{m}^{-2} \mathrm{~h}^{-1}$ associated with the use of different measurement techniques (Helmig et al., 1998; Karl et al., 2007; Kuhn et al., 2007). Overall, the emission reduction inferred by the satellite observations lies within the variability of the field measurements, while the discrepancies between the observed fluxes are often larger than the differences between the a priori and a posteriori fluxes. The field studies generally agree on higher fluxes during the dry and the dry-to-wet transition season between July and December (Simon et al., 2005), while a recent field campaign suggests much lower fluxes (by ca. a factor of 3 ) compared to the top-down estimates, most likely related to a local effect of leaf flushing at the measurement location (Alves et al., 2016).

\section{African emissions}

In northern Africa, the biomass burning source is reduced by the inversion by $15-38 \%$ for the different years and lies closer to GFED4, GFAS, and FINN estimates (Table 1; Fig. 11). In this region, both natural and agricultural fires peak in December, but the agricultural fire season, from September to May, lasts longer than the season of natural fires, which generally occurs between November and March (Magi et al., 2012). The OMI observations suggest a ca. 50\% 

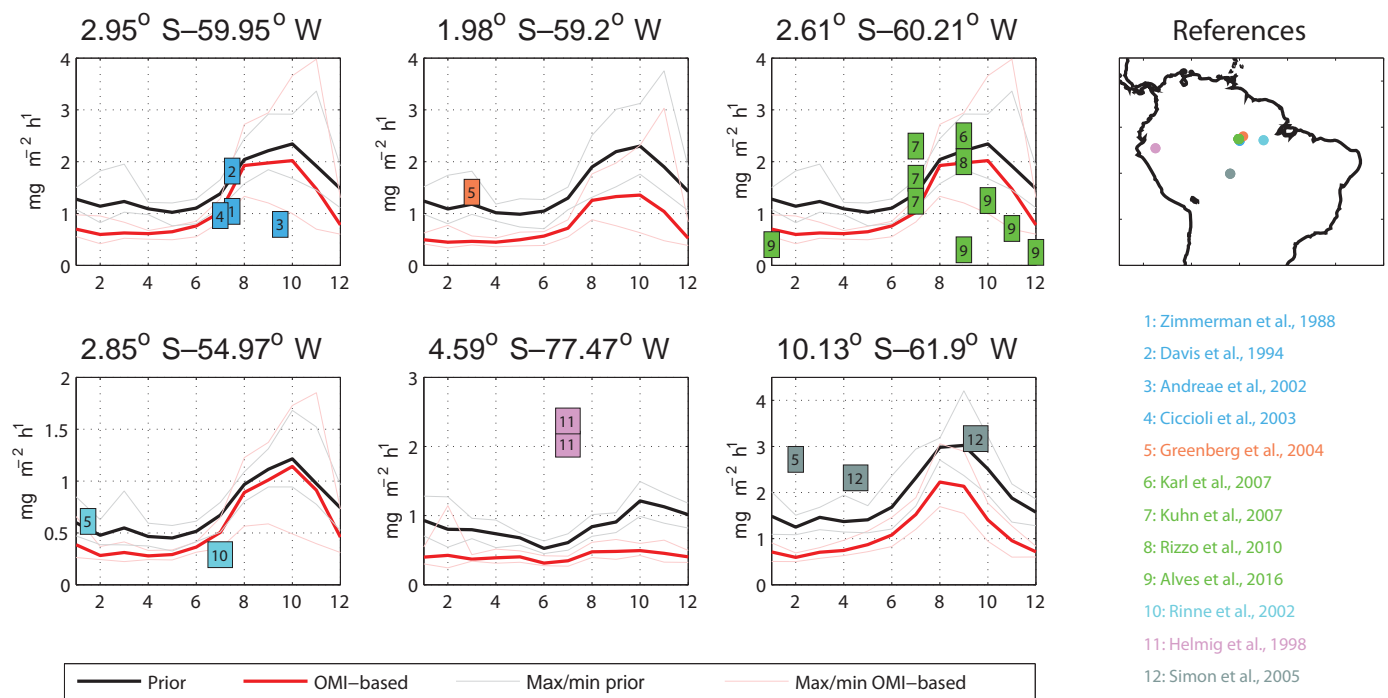

Max/min OMl-based

12: Simon et al., 2005

Figure 10. Comparison of a priori (black) and satellite-based (red) isoprene fluxes with ground-based flux measurements (colored numbered squares). The a priori and a posteriori isoprene fluxes are averaged over the full period from 2005 to 2013 for the grid. To ensure meaningful comparison, the ground-based flux measurements are corrected for the diurnal variation in isoprene fluxes; cf. Table S1 for more details.

emission decrease in the fire peak season, which is supported by comparisons with GFAS and FINN inventories (Fig. 11), and a moderate increase from February to April when the agricultural fires are dominant and when the fraction of small fires is largest according to GFED4s. Higher emissions from February to April are also supported by GFAS and FINN, suggesting an even stronger shift in the fire season, with higher fire emissions lasting until May. The reduced emission amplitude and the longer burning season in northern Africa are corroborated by an inversion study using $\mathrm{CO}$ columns from the MOPITT instrument (Chevallier et al., 2009).

In Africa south of the equator, the OMI-based fire source is $23 \%$ lower than the bottom-up estimate and lies closer to the estimates of GFED4, GFAS, and FINN (Table 1; Fig. 11). In terms of seasonal variation, the natural fires open the fire season between April and October, followed by agricultural fires lasting from June to November (Magi et al., 2012). The inversion infers $21 \%$ lower emissions in the beginning of the fire season, when fires are predominantly natural, a reduction by $43 \%$ during the fire peak between July and September, and $20 \%$ higher emissions than GFED4s in October, when agricultural fires are the prevalent source (Fig. 11). The GFED4s inventory allocates the maximum of the small-fire fraction to the peak of the fire season (Randerson et al., 2012), resulting in an enhanced emission peak in July-August, rather than in September, as suggested by the OMI observations. This seasonality shift of the burning season was also reported in past inversion studies constrained by SCIAMACHY and GOME2 HCHO (Stavrakou et al., 2009b, 2015) and MOPITT CO observations (Chevallier et al., 2009).

Southern Hemisphere Africa can be divided into two regions based on the fire source updates suggested by OMI
(Fig. 5). In its northern part, reduced emissions are systematically derived for all years, by up to $65 \%$, with regard to the a priori flux, whereas in its southern part (southern Africa in Fig. 3), the emissions exhibit a stronger variability, increasing significantly until 2010 but remaining closer to the a priori in the subsequent years, as illustrated in Fig. 5. The a posteriori emissions during the peak fire season in September are found to be up to a factor of 3 higher than FINN and 50\% higher than GFAS and GFED4. The largest top-down flux in this region is inferred in September 2008, estimated to be $50 \%$ higher than the a priori, due to record-high wildfires in Mozambique, South Africa, and Swaziland in that year (Jha, 2010).

The OMI observations suggest a decrease in isoprene fluxes over the African continent by ca. $20 \%$ for all years of the target period, from $79 \mathrm{Tg}_{\mathrm{year}}{ }^{-1}$ in the a priori to $63 \mathrm{Tg}_{\text {year }}{ }^{-1}$, as shown in Table 1 . This decrease is very similar to the result obtained from an inversion study constrained by the NASA OMI HCHO retrieval product reporting an emission reduction in African isoprene fluxes, from $87 \mathrm{Tg}$ year $^{-1}$ in the a priori to $68 \mathrm{Tg}_{\text {year }}{ }^{-1}$ through $2005-$ 2009 (Marais et al., 2012). In the latter study, the flux decrease was strongest over equatorial and northern Africa, in very good agreement with the updates shown in Fig. 6. In a follow-up inversion study also based on OMI observations, Marais et al. (2014) invoked a reduction in MEGAN emission factors for broadleaf trees and shrub (ca. factor of 2) and woody savannas $(20 \%)$ in Africa in order to reconcile the model with the observations, whereas the reported comparisons with ground-based measurements suggested that even lower isoprene flux rates may be necessary. 

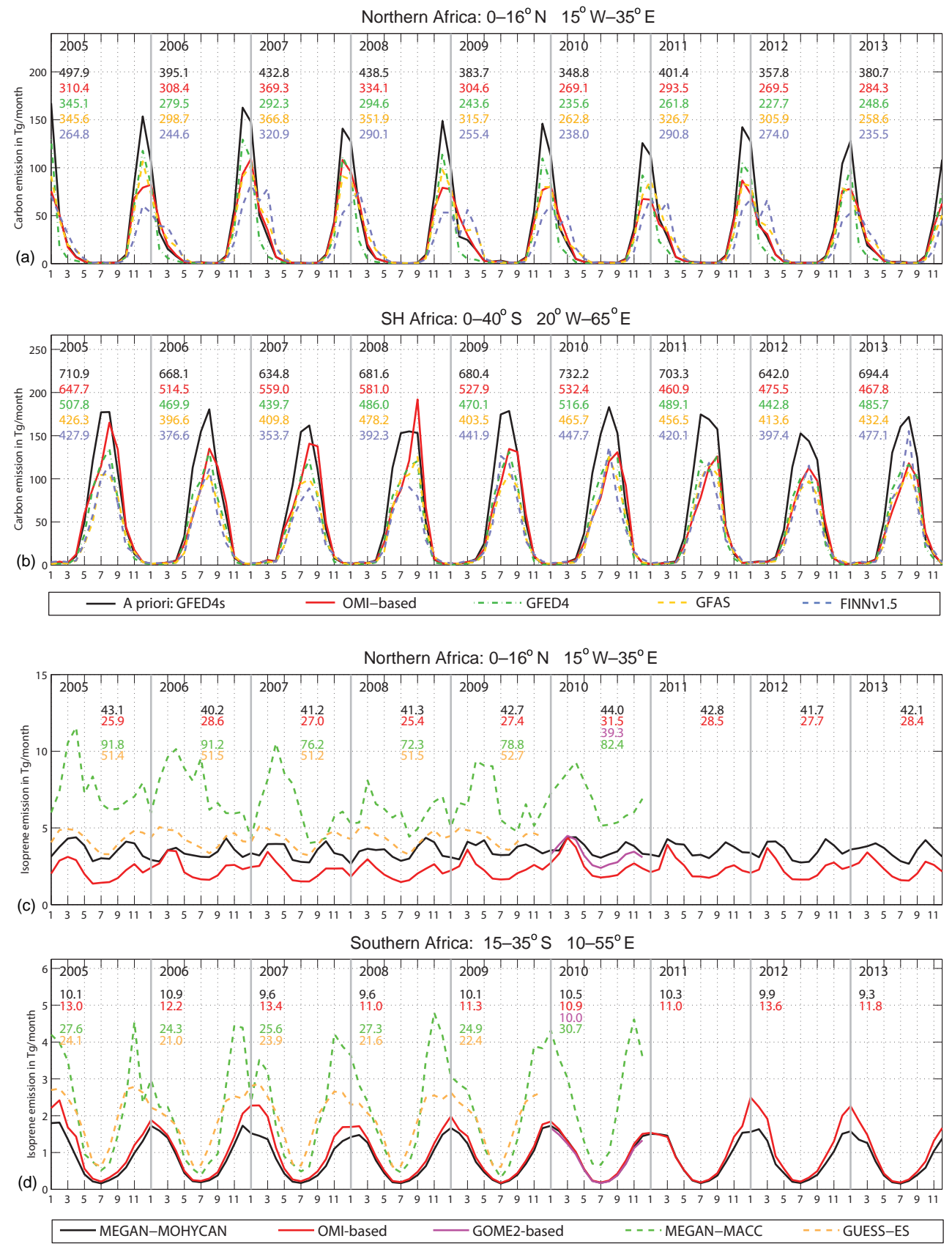

Figure 11. As Fig. 9 but for Africa.

The isoprene fluxes in northern Africa exhibit a weak interannual variability (Figs. 8, 11). The OMI observations point to a mean (2005-2013) decrease of $26 \%$ in this region with respect to the bottom-up estimate. The geographical extent of the emission updates (Fig. 6) is in agreement with previous satellite-based results using SCIAMACHY (Stavrakou et al., 2009b) and GOME-2 HCHO columns (Bauwens et al., 2014; Stavrakou et al., 2015). As seen in Fig. 11, the seasonality of isoprene emissions in northern Africa is characterized by two emission maxima, driven by the two equatorial rainy seasons occurring from March to May and from $\mathrm{Au}-$ gust to November. The satellite columns indicate a change in the seasonal profile, from two equally strong emission maxima in April-May and in October to a peak in March and a weaker second peak in October-November (Fig. 11). This agrees with the seasonality derived from GOME-2 observations and is similar to the seasonality change reported by Marais et al. (2012). The stronger emissions in the first half of the year are also consistent with the independent invento- 
ries, whereas the secondary peak is better represented in the GUESS-ES inventory.

The isoprene emissions in southern Africa peak during the Southern Hemisphere summer, when both temperature and precipitation rates are higher (Fig. 11). Both MEGANMACC and GUESS-ES emission estimates are about a factor of 2 higher than the top-down estimates. The discrepancy with MEGAN-MACC is partly explained by the neglect of the soil moisture stress effect $\left(\gamma_{\mathrm{SM}}\right)$ in the standard version of the MEGAN-MACC model. Its inclusion in MEGAN-MACC was found to have a strong impact, leading to a flux decrease by $50 \%$ on a global scale and even stronger decreases in Africa and South America (Sindelarova et al., 2014). Interestingly, the inversion suggests a large increase in isoprene emissions (up to a factor of 2) southward of $15^{\circ} \mathrm{S}$ and particularly in the very dry southwestern part of the continent (west of ca. $30^{\circ} \mathrm{E}$ ), where the soil moisture stress effect is strongest in the MEGAN-MOHYCAN emissions (Fig. 6 and Fig. 2 in Müller et al., 2008). The spatial coincidence of the largest emission updates inferred by the inversion with the areas where the soil moisture stress effect is strongest is a first indication that its parameterization in MEGAN overestimates the impact of very low soil moisture on the emissions in dry subtropical environments like southern Africa (also Australia; see Sect. 7). A second, even stronger indication is provided by the interannual variability of the emission updates in southwestern Africa $\left(15-35^{\circ} \mathrm{S}\right.$, $10-30^{\circ}$ E) shown on Fig. 12. These updates are indeed found to be well correlated $(r=0.81)$ temporally with the factor by which the emissions are reduced due to the soil moisture activity factor $\gamma_{\mathrm{SM}}$. In other words, the emission increments are largest when and where $\gamma_{\mathrm{SM}}$ is lowest.

MEGAN simulates the isoprene response to soil moisture stress with a simple parameterization that shuts off isoprene emission when soil moisture drops to the level where plants can no longer draw moisture from the soil, known as the wilting point. While the MEGAN soil moisture stress effect uses a simple concept, the implementation is difficult due to the need to accurately model soil moisture, soil wilting point, and plant rooting depth. Seco et al. (2015) evaluated the MEGAN response to soil moisture stress by comparison to measured whole canopy isoprene fluxes and found that the algorithm performed poorly with the default soil wilting point but worked well when a more accurate value was used.

\section{Emissions in southeast Asia}

The fire season in southeast Asia is characterized by a first peak in March, associated with aboveground vegetation burning in Indochina, and a second peak in August to October caused by peat combustion occurring in Indonesia (Chang and Song, 2010) (Fig. 13). The GFED4s fluxes vary considerably across the years, ranging between a minimum of $123 \mathrm{Tg} \mathrm{C}$ (in 2011) and $277 \mathrm{Tg} C$ (in 2006). The top-
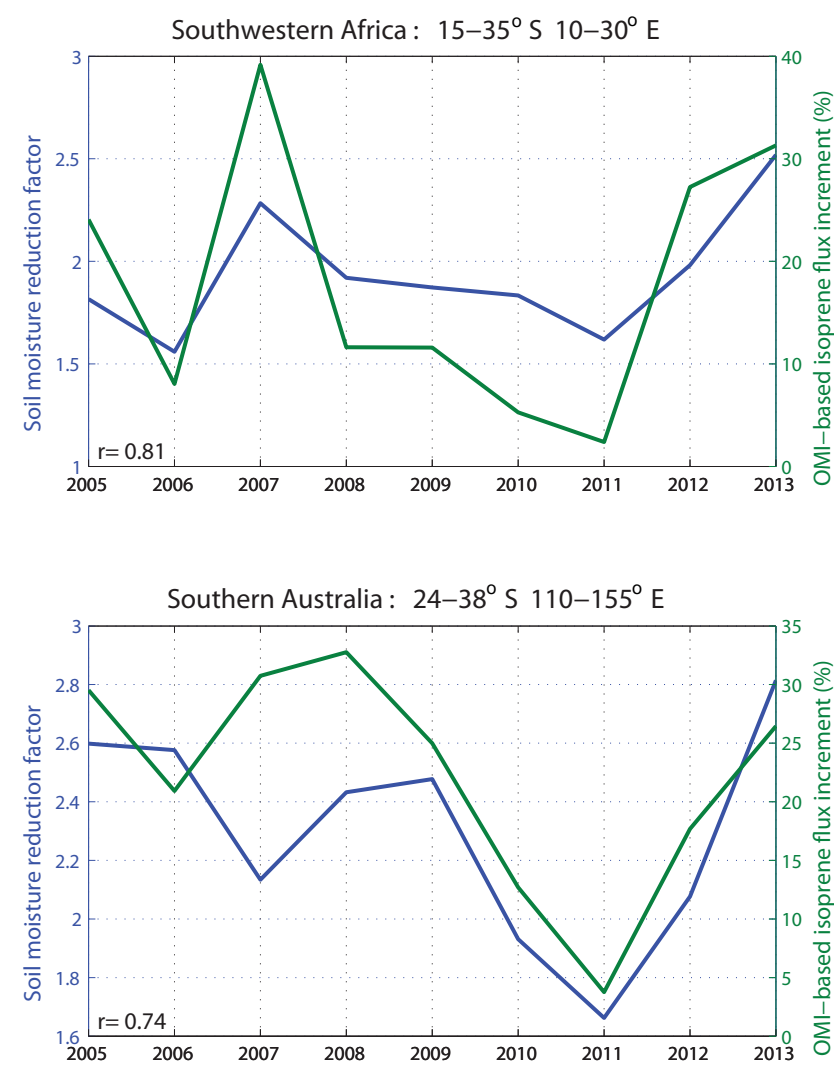

Figure 12. Interannual evolution of the factor by which the annual isoprene flux is reduced due to soil moisture stress vs. the isoprene flux increment inferred from OMI data (in \%) in southwest Africa (top) and southern Australia (bottom).

down estimates remain generally close to the a priori, except in 2006 and 2009, when the satellite observations suggest a significant decrease in the fluxes associated with peat burning in Indonesia (Reddington et al., 2014) by almost a factor of 3 (Fig. 13). The optimized fluxes generally increase in March and decrease from August to October, while the amplitude of the seasonal pattern is reduced, with the emissions in March being generally larger than the peat burning emissions in August. In addition, the higher a posteriori correlation with monthly MODIS fire counts in Indochina (Table 3) indicates an improved representation of the seasonal natural fires in March-April and agricultural waste burning in AprilMay (Magi et al., 2012).

In Indonesia, the fire season extends from June to November and comprises intense peat burning, in particular during extreme drought conditions caused by El Niño (Schultz et al., 2008; Worden et al., 2013). The GFED4s estimates are generally lower than $100 \mathrm{Tg} \mathrm{C}_{\text {year }}{ }^{-1}$ but significantly higher for El Niño years, e.g., 2006 (350.3 Tg C) and 2009 $\left(191.6\right.$ Tg year $\left.^{-1}\right)$. The inferred flux drop in 2006 and 2009 is supported by GFAS and FINN, but in all other years both FINN and GFAS are relatively close to GFED4s. The lower 2006 flux suggested by the observed columns is corroborated 

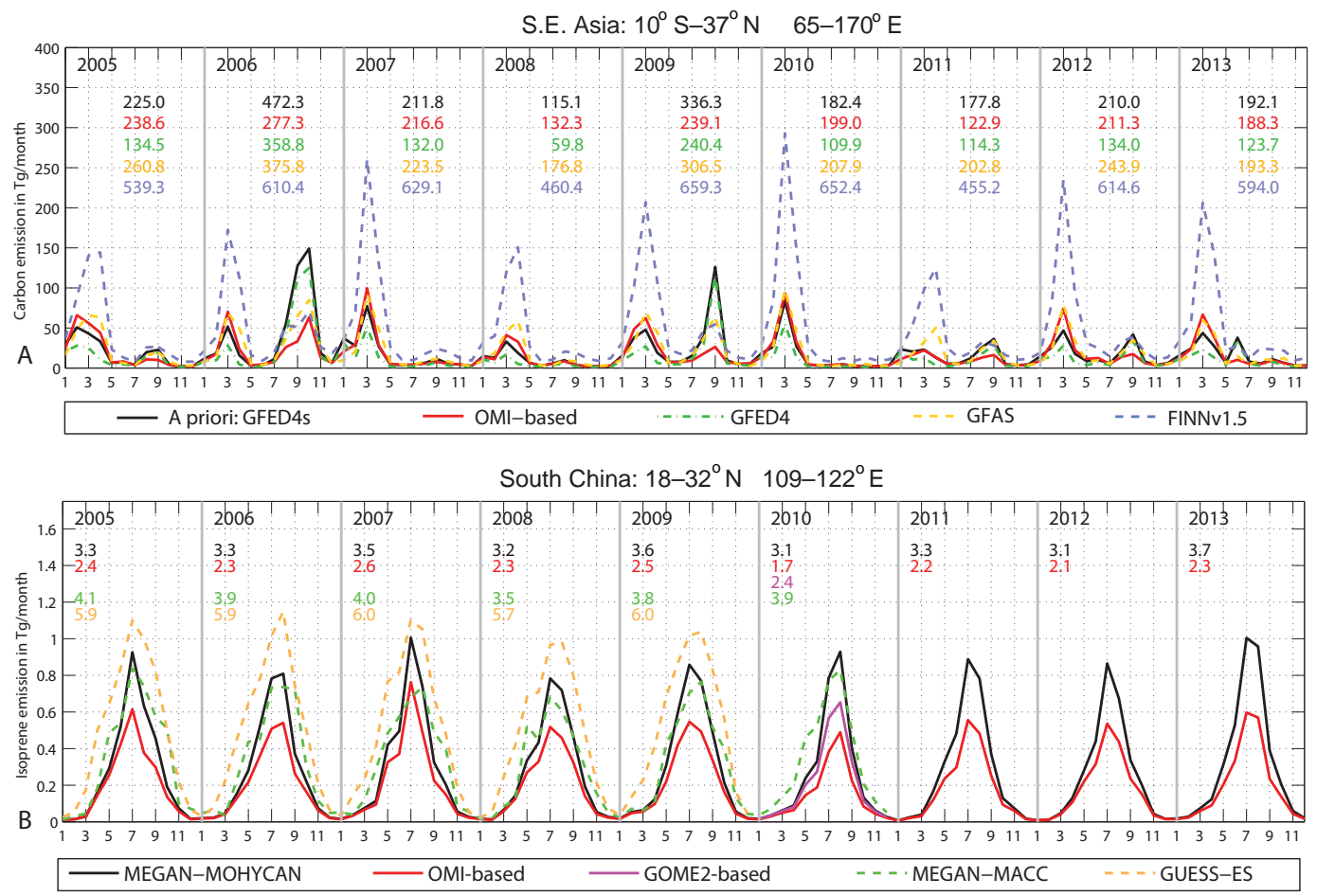

Figure 13. As Fig. 9 but for southeast Asia.

by an independent carbon emission estimate based on burned area in a small region of Borneo in 2006 (Central Kalimantan, approximately $13 \%$ of the Indonesian peatland) reporting peat fire emissions of $49 \mathrm{Tg} \mathrm{C}$ during the $2006 \mathrm{El}$ Niño episode (Ballhorn et al., 2009). This estimate is about half of the GFED4s value (109 Tg C) and closer to the OMIbased estimate of $33 \mathrm{Tg} \mathrm{C}$ for the same area and year. Note, however, that this independent estimate does not account for aboveground biomass burning.

As mentioned in the previous sections, the updated isoprene emissions are systematically decreased in tropical regions, by about $40 \%$ on average in Amazonia and equatorial Africa (Fig. 6), pointing to potentially overestimated emission factors used in the MEGAN model for tropical forests. In contrast to these regions, the emission reduction for the tropical rainforests of southeast Asia is much weaker $(<20 \%$; Figs. 6, 8) due to the lower basal emission rates incorporated in MEGAN-MOHYCAN (Stavrakou et al., 2014) based on OP3 campaign measurements in the rainforest of Borneo (Langford et al., 2010). The relatively small discrepancy between the model and the satellite HCHO columns in southeast Asia supports the use of lower isoprene flux rates for the Asian rainforests.

In China, most of the fires are agricultural and their emissions are generally low, except for the North China Plain (Fig. 5, Stavrakou et al., 2016a). The isoprene fluxes in China are also reduced after optimization, from $7.3 \mathrm{Tg}_{\mathrm{year}}{ }^{-1}$ in MEGAN-MOHYCAN to $5.8 \mathrm{Tg}$ year $^{-1}$ on average over the study period, but the decrease is stronger in south China, ranging between 27 and $45 \%$ depending on the year. The emissions peak in summertime and present weak interannual variability (Fig. 8), with a maximum in 2007 (2.6 Tg year $^{-1}$ ) and a minimum in 2010 (1.7 $\mathrm{Tg}_{\text {year }}{ }^{-1}$; Fig. 13). The OMIbased flux in 2010 is in good agreement with an earlier estimate inferred from GOME-2 HCHO observations (2.4 Tg year ${ }^{-1}$; Fig. 13) (Stavrakou et al., 2015).

\section{Australian emissions}

Northern Australia is a major fire-prone area, where bushfires occur during many months every year (Steffen et al., 2015). The peak of the fire season is observed between September and November, but its magnitude depends strongly on the year. The fire season begins between April and June, with the beginning of the dry season, is reinforced by the hot temperatures and winds of the subsequent months, and lasts until December. The OMI data suggest top-down fluxes close to the a priori in all years, except for 2011, when the emission maximum is decreased by about $25 \%$ with respect to GFED4s (Fig. 14), whereas the estimates from GFAS and FINN in this region differ by more than a factor of 10 . In southern Australia (Fig. 14), the fire fluxes are generally half those in northern Australia, and bushfires are again the main fire type in this region. This region, and in particular the state of Victoria, sometimes experiences extreme fire events, like the 2006-2007 bushfires, which were some of the worst on 

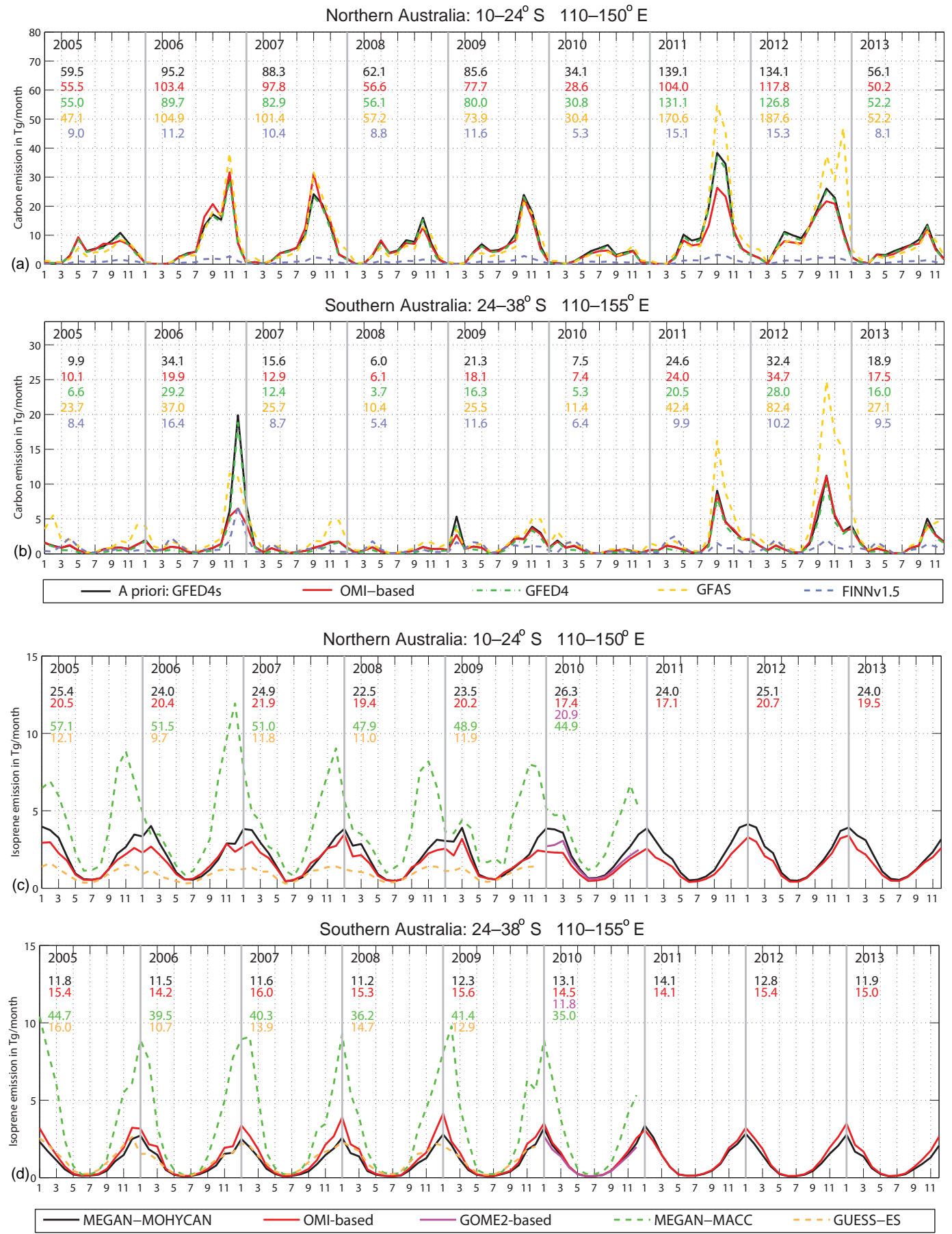

Figure 14. As Fig. 9 but for northern and southern Australia.

record, and the "Black Saturday" bushfires in February 2009. The satellite columns of HCHO lead to a significant reduction (Fig. 14) in the fire emission during the aforementioned major fire events in comparison to the GFED4s inventory, in good agreement with the FINN estimates.

The optimization indicates negative isoprene updates in the tropical and subtropical ecosystems of northern Aus- tralia, which are dominated by woodland and grasslands, and generally positive flux increments in the southern part of the continent, where temperate forests and grasslands are prevalent (Figs. 8, 14). The mean reduction over 2005-2013 in northern Australia amounts to ca. $20 \%$ with respect to the a priori $\left(24.4 \mathrm{Tg}_{\text {gear }}{ }^{-1}\right)$ and is supported by the inversion study based on GOME-2 HCHO columns (Stavrakou et al., 

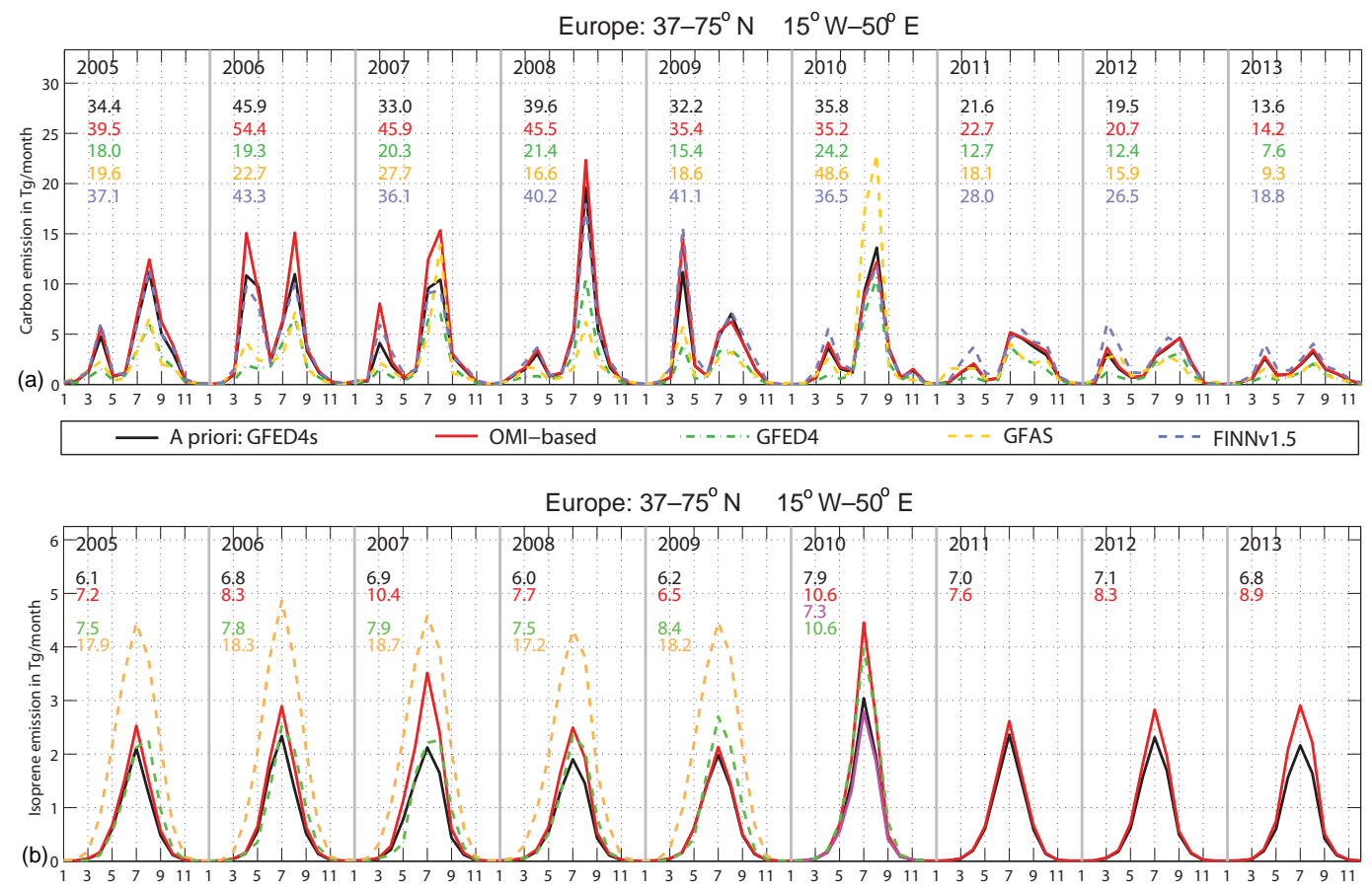

SE US: $26-36^{\circ} \mathrm{N} \quad 75-100^{\circ} \mathrm{W}$

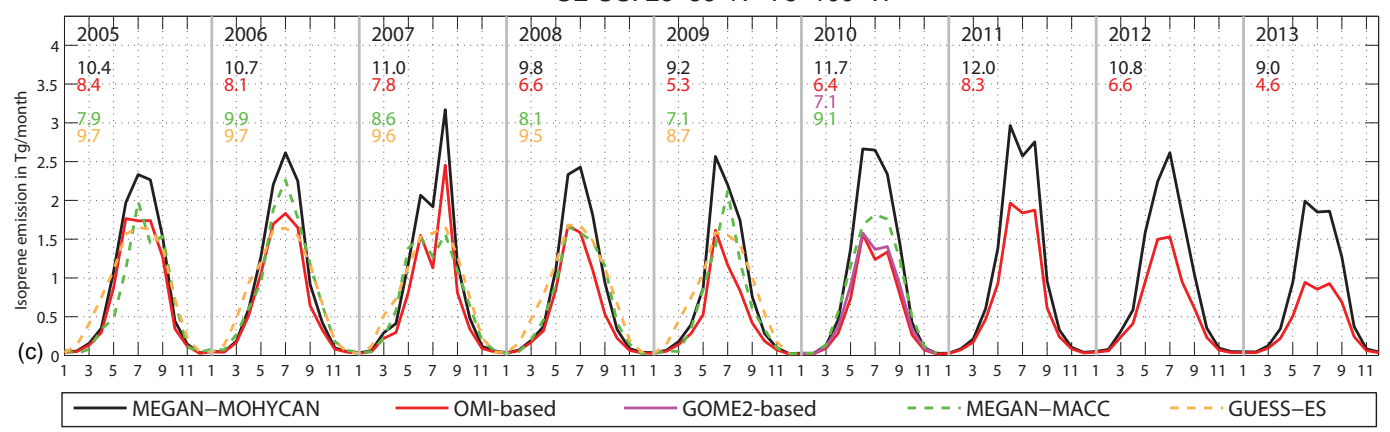

Figure 15. As Fig. 9 but for Europe and the southeast US.

2015) as shown in Fig. 8, pointing to possibly overestimated emission factors assumed in MEGAN for tropical ecosystems. In southern Australia, the a posteriori isoprene fluxes are increased by about $20 \%$ on average over the study period, from 12.5 to $15 \mathrm{Tg} \mathrm{year}^{-1}$, and show small interannual and seasonal variability (Fig. 14). Although the MEGANMACC emissions are much higher than the other inventories over Australia, a sensitivity calculation accounting for the soil moisture stress activity factor in the MEGAN-MACC model resulted in a substantial flux decrease of about $70 \%$ with respect to the reference MEGAN-MACC simulation (Sindelarova et al., 2014), stressing the important role of soil moisture stress in these very dry environments. As for southern Africa, the OMI-based inversion over southern Australia enhances the emissions where and when $\gamma_{\mathrm{SM}}$ reaches its lowest values (Figs. 6 and 12). As discussed above, the poor performance of the parameterization could be partly due to misrepresentations of driving variables (soil moisture content) or soil characteristics (wilting point, rooting depth). The use of satellite-derived soil moisture or solar-induced fluorescence (van der Molen et al., 2016; Joiner et al., 2016) could be a promising way for improving the soil stress estimation in the future.

\section{Midlatitude emissions}

In Europe, the fire season peaks in summertime and a secondary peak is also recorded in spring, mainly due to emissions from agricultural waste burning (Fig. 15). The optimized fluxes lie generally close to the a priori except in 2006 and 2007, when the OMI observations point to higher fluxes (by 40-50\%) than in GFED4s during the emission peak. The strong fluxes in April-May 2006 and in summer 2007 were due to numerous agricultural fires that occurred in the Baltic countries, western Russia, Belarus, and Ukraine (Stohl 


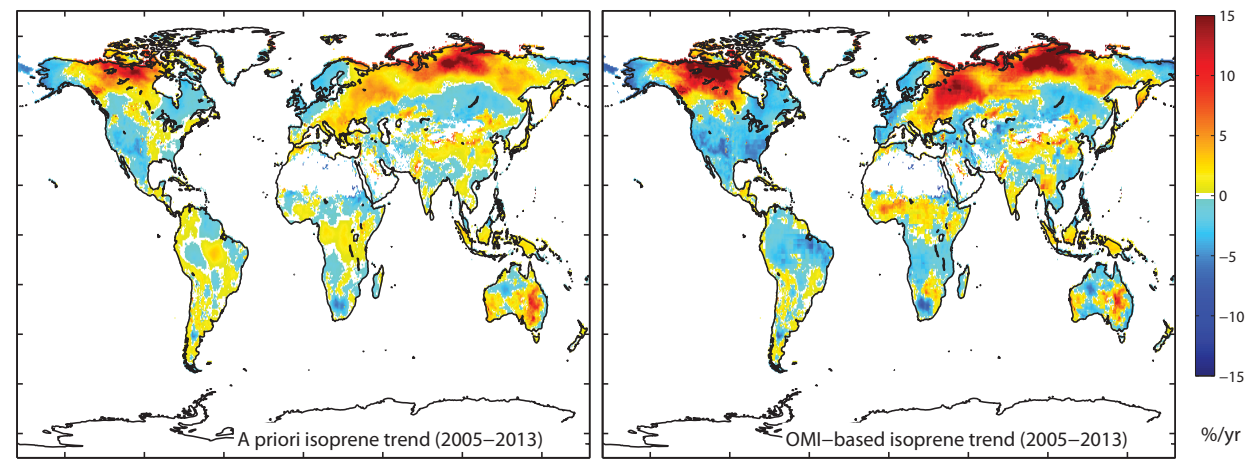

Figure 16. Global distribution of annual isoprene emission trends over 2005-2013 according to the a priori (left) and top-down inventory (right) expressed in percentage year ${ }^{-1}$.

et al., 2007) and to intense biomass burning in southern Europe. The increase in the top-down estimates in 2007 is in line with the reported increase based on IASI CO columns (Turquety et al., 2009). The top-down estimate agrees well with GFED4s during the devastating fires in the Moscow area in July-August 2010, whereas previous studies reported values which were a factor of 2 (Yurganov et al., 2010), 3 (Konovalov et al., 2011), and 10 (Krol et al., 2013) higher than the older GFED3 inventory (van der Werf et al., 2010), which was about $60 \%$ lower than GFED4s in this region.

Regarding isoprene fluxes over Europe, the satellite observations suggest an average increase by $15 \%$ in western Europe (from 2.9 to $3.4 \mathrm{Tg}_{\text {year }}{ }^{-1}$ ) and by $33 \%$ in eastern Europe (from 3.9 to $5.2 \mathrm{Tg} \mathrm{year}^{-1}$ ), whereas the inferred increase is significantly stronger during extremely hot summers, like in 2007 and 2010. Indeed, in July 2007 Greece experienced the hottest summer on record since 1891 (Founda and Giannakopoulos, 2009), with temperature anomalies of $+5^{\circ} \mathrm{C}$ compared to the 1961-1990 mean, and in July 2010, the hottest summer since 1500 was recorded in western Russia, with temperature anomalies of $+6^{\circ} \mathrm{C}$ with respect to the 1961-1990 mean (Barriopedro et al., 2011; Coumou and Rahmstorf, 2012) (http://www.ncdc.noaa.gov/ temp-and-precip).

The concurrence of pyrogenic and isoprene emissions in the mid- and high latitudes of the Northern Hemisphere during summertime is, however, an inherent difficulty in the derivation of top-down emissions by inverting for $\mathrm{HCHO}$ columns. HCHO being an intermediate compound in the oxidation of both pyrogenic and biogenic hydrocarbons, it cannot be excluded that the HCHO column enhancements associated with higher isoprene emissions have in reality a pyrogenic origin and vice versa. The inversion scheme relies strongly on the a priori emission distributions and errors in the retrievals, and, thereby, errors in the geolocation of fire hot spots in the bottom-up inventories could propagate as errors in the source attribution, in particular for intense fire events associated with summer heat waves.
In the southeastern US, a major isoprene-emitting region, the top-down fluxes are systematically reduced compared to the initial inventory, by $35 \%$ on average, with the strongest decrease $(50 \%)$ inferred in 2013. Similarly to the a priori, the a posteriori estimates peak in 2011 and are lowest in 2013. This variability is primarily related to temperature changes, with recorded temperature anomalies of $+3{ }^{\circ} \mathrm{C}$ in 2011 and $-1.5^{\circ} \mathrm{C}$ in 2013 with respect to the $1961-1990$ mean (http://www.ncdc.noaa.gov/temp-and-precip/). The use of GOME-2 HCHO columns to constrain the inversion in 2010 (Stavrakou et al., 2015) results in an excellent agreement with the OMI-based fluxes (Figs. 8 and 15), whereas both optimizations suggest a slightly modified seasonal profile, with a primary peak in June and a secondary one in August. The need for lower emissions in the southeastern US compared to the MEGAN model has been put forward by past studies based on satellite observations of HCHO from GOME, SCIAMACHY, and OMI sensors (Palmer et al., 2006; Millet et al., 2008; Stavrakou et al., 2009b). The MEGANMACC and GUESS-ES estimates are in very good agreement with the a posteriori fluxes in terms of magnitude, although in some years the peak emission is delayed by 1 month (Fig. 15).

\section{Emission trends}

The global distribution of isoprene emission trends over 2005-2013 according to the bottom-up emission inventory and as suggested by the inversion of satellite data is displayed in Fig. 16. Although deriving long-term emission trends from satellite data may be very useful for diagnosing global and regional change, particular caution is required when interpreting the results, since physical changes in the satellite instruments over time may result in artificial drifts in the observations. In the case of OMI $\mathrm{HCHO}$ columns, special efforts were made to reduce the effects of the row anomaly issue (http://projects.knmi.nl/ omi/research/product/rowanomaly-background.php) on the 
retrieved $\mathrm{HCHO}$ columns, in order to ensure the suitability of the data for addressing trend studies (De Smedt et al., 2015). Nevertheless, it appears difficult to avoid any time-dependent instrumental effect possibly impacting the interannual variability of emissions reported in this section.

Amazonia experienced a rapid decline in pyrogenic emissions, estimated to be $-7 \%$ year $^{-1}$ in the a priori GFED4s inventory and $-8 \%$ year $^{-1}$, in the OMI-based emissions as a result of the trend in OMI columns calculated during the dry season $\left(-3.2 \%\right.$ year $^{-1}$ in August-September). This trend in $\mathrm{HCHO}$ columns was attributed to a strong decline in deforestation rates in the Amazon (Nepstad et al., 2014) and especially in Mato Grosso and Rondônia, where the cover loss in evergreen broadleaf forests decreased by more than $80 \%$ between 2002 and 2009 (Fanin and van der Werf, 2015). The isoprene emission trend over Amazonia, which is close to negligible $\left(-0.2 \%\right.$ year $\left.^{-1}\right)$ in the a priori inventory (Figs. 9 and 16), becomes negative after optimization $\left(-2.1 \%\right.$ year $\left.^{-1}\right)$. The derivation of biogenic emission trends in this region is made difficult by the magnitude and strong interannual variability of biomass burning. However, a decline in isoprene emissions is supported by the negative trend $\left(-1.3 \%\right.$ year $\left.^{-1}\right)$ in the observed HCHO columns during the wet season (November-April), when biomass burning plays only a very minor role. This result is difficult to interpret. Recent findings based on satellite surface reflectance data (more precisely, normalized difference vegetation index, or NDVI, data) point to diminished vegetation greenness since 2000 due to a precipitation decline across large parts of Amazonia, especially northern Brazil (Hilker et al., 2014). However, most of these changes occurred between 2000 and 2005, whereas the precipitation rates and NDVI values were comparatively more stable afterwards, and the leaf area index from MODIS Collection 5 (MOD15A2 composite, http://modis.gsfc.nasa.gov/data/dataprod) either increased (by less than $0.5 \%$ year $^{-1}$ ) or showed no trend over 2005-2013 over most of Amazonia (see Fig. S5).

Over northern Africa, during the fire season (NovemberFebruary) a decreasing trend of about $3 \%$ year $^{-1}$ over the study period is derived for the OMI-based fire fluxes (Fig. 7), close to the GFED4s trend $\left(-3.2 \%\right.$ year $\left.^{-1}\right)$, whereas the corresponding trend of FINN $\left(-2.4 \%\right.$ year $\left.^{-1}\right)$ is somewhat weaker. This trend is most likely related to negative trends observed in burned area in northern Africa (Andela and van der Werf, 2014; Giglio et al., 2013), owing to land use changes (conversion of savannah into cropland) and to changes in precipitation, driven by the El Niño-Southern Oscillation (Andela and van der Werf, 2014).

In Siberia, the strongly positive isoprene emission trend of the bottom-up inventory (3.8\% year ${ }^{-1}$ ) (Fig. 16) is a result of the warming temperature trends in this region $\left(0.12^{\circ} \mathrm{C}_{\text {year }^{-1}}\right.$ over $55-75^{\circ} \mathrm{N}, 40-120^{\circ} \mathrm{E}$, based on ECMWF ERA-Interim temperature data over 2005-2013). The model incorporates both the direct effect of warming on the MEGAN temperature response of the emissions and the indirect effect through the increase in leaf area index (LAI), which reaches $3 \%$ year $^{-1}$ in northern Siberia (Fig. S5). The inversion leads to an even higher trend $\left(4.2 \%\right.$ year $\left.^{-1}\right)$, induced by the strongly positive trend in the HCHO observations (4.2\% year $^{-1}$ ) over 2005-2013 in this region, suggesting a stronger response of isoprene emissions to warming. This result is in line with reported ecosystem measurements in the Arctic exhibiting a higher emission response of biogenic emissions than observed at more southern latitudes (Kramshøj et al., 2016). Higher temperatures may also favor the extension of forests inducing even higher isoprene emissions (Potosnak et al., 2013). According to MODIS land cover data, the forest fraction in this region has increased from $31 \%$ in 2005 to $36 \%$ in 2012 (Friedl et al., 2010).

Opposite a priori isoprene trends are calculated in western and eastern Europe over the study period, -2.5 and $3.2 \%$ year $^{-1}$, respectively, mostly related to the temperature and solar radiation trends. The OMI observations corroborate these trends, showing a negative trend in western Europe $\left(-1.1 \%\right.$ year $\left.^{-1}\right)$ and a positive trend in eastern Europe $\left(0.4 \%\right.$ year $\left.^{-1}\right)$. The calculated trends after optimization are moderately enhanced: -3.3 and $3.9 \%$ year $^{-1}$ in western and eastern Europe, respectively. Besides climate parameters, land use changes may also contribute to the increasing column and emission trend in eastern Europe. Based on MODIS land cover data (Friedl et al., 2010), the forest fraction increased at a faster pace in eastern than in western Europe ( $1.1 \%$ year vs. $0.9 \%$ year $\left.^{-1}\right)$ and the crop fraction decreased more rapidly $\left(-0.5 \%\right.$ year $\left.^{-1}\right)$ in eastern than in western Europe $\left(-0.4 \%\right.$ year $\left.^{-1}\right)$.

Over the southeastern US, the slightly negative trend in the summertime isoprene fluxes in the a priori $\left(-0.3 \%\right.$ year $\left.^{-1}\right)$ becomes much more pronounced after inversion $\left(-4 \%\right.$ year $\left.^{-1}\right)$, induced by the downward trend in the OMI HCHO columns (-2.5\% year $\left.{ }^{-1}\right)$ over 2005-2013 (De Smedt et al., 2015). Except for this trend, the interannual variability of the top-down emissions over this region is similar to the a priori (Fig. 8). The long-term decline could be in part an artifact resulting from the well-documented downward trend in $\mathrm{NO}_{x}$ abundances over the United States (Russel et al., 2012; Kharol et al., 2015), which could significantly decrease formaldehyde production over time if the yield of HCHO per isoprene molecule is substantially lower at low $\mathrm{NO}_{x}$ level than at high $\mathrm{NO}_{x}$. The ground-level $\mathrm{NO}_{2}$ concentrations have decreased by as much as a factor of 2 over the eastern US based on OMI and in situ measurements between 2005 and 2012 (Kharol et al., 2015). The $\mathrm{NO}_{x}$ dependence of the HCHO yield is taken into account in the calculations presented in this study, but the modeled decrease in planetary boundary layer (PBL) $\mathrm{NO}_{x}$ level in the eastern US is lower (ca. $-30 \%)$ than observed $(-50 \%)$ during 2005-2012. Furthermore, the low- $\mathrm{NO}_{x}$ oxidation mechanism remains incompletely characterized, especially regarding the further degradation of primary oxidation products, leaving open the possibility of a significant overestimation 
of the $\mathrm{HCHO}$ yield at low $\mathrm{NO}_{x}$, even though a recent analysis of airborne measurements over the southeast US indicated that state-of-the-art oxidation mechanisms can reproduce the $\mathrm{NO}_{x}$ dependence of prompt $\mathrm{HCHO}$ formation inferred from the measurements (Wolfe et al., 2016). If confirmed, an overestimation of the $\mathrm{HCHO}$ yield at low $\mathrm{NO}_{x}$ could also help to explain the negative trend in top-down isoprene emission over western Europe (Fig. 16). More importantly, it would imply a general underestimation of our top-down emissions in low- $\mathrm{NO}_{x}$ environments and tropical forests in particular.

In south China, the negative summertime trend $\left(-0.7 \%\right.$ year $\left.^{-1}\right)$ in HCHO columns drives a change in the sign of the 2005-2013 isoprene trend: from $0.1 \%$ year $^{-1}$ in the a priori to $-1.6 \%$ year $^{-1}$ in the OMI-based fluxes. The very small a priori emission trend results from a combination of compensating effects: on the one hand, declining trends in the ERA-Interim photochemically active radiation (PAR) $\left(-0.33 \%\right.$ year $\left.^{-1}\right)$ and temperature $\left(-0.03 \mathrm{~K} \mathrm{year}^{-1}\right)$, and on the other hand, an increasing trend in leaf area index (1\% year ${ }^{-1}$, cf. Fig S5) and a decline in crop extent in south China, suggested by the land use database of Ramankutty and Foley (1999) and supported by MODIS land cover data (Friedl et al., 2010). However, a recent land cover database suggests that the extent of crops has increased in eastern China in the last 30 years (Hurtt et al., 2011). In addition, the declining trend in PAR was also derived from ERA-Interim data complemented by surface radiation measurements (Weedon et al., 2014). The crop expansion and declining PAR were proposed to cause a negative isoprene trend in south China (Yue et al., 2015) and likely explain the observed negative trend in $\mathrm{HCHO}$.

\section{Conclusions}

Global distributions of pyrogenic and biogenic VOC fluxes between 2005 and 2013 were derived using the adjoint inversion scheme built on the IMAGESv2 global CTM and HCHO column abundances retrieved from the OMI sounder. The inversion suggests a moderate decrease (ca. $20 \%$ ) in the global average emissions of both pyrogenic and biogenic VOCs relative to the a priori emissions used in the model. The main findings of this study are presented below.

- The global top-down fire fluxes exhibit strong interannual variability, ranging between ca. $1400 \mathrm{Tg} \mathrm{C}_{\text {year }}{ }^{-1}$ (2011) and $2000 \mathrm{Tg} \mathrm{C}$ year $^{-1}$ (2007). The a priori interannual variability is generally well preserved, but the inferred estimates are ca. 250 to $450 \mathrm{Tg} \mathrm{C}$ lower than the a priori, depending on the year, with the largest decreases suggested over Africa, South America, and southeast Asia (23\%). The top-down emissions are better correlated with MODIS than GFED4s fire counts in regions with small fires, indicating that the associated emissions may be too low in GFED4s and that they can be derived by the OMI-based inversion.
- The inversion suggests (i) important fire flux decreases $(15-30 \%)$ in Amazonia during years with strong a priori emissions, (ii) about a $50 \%$ emission decrease during the peak fire season in northern and southern Africa, (iii) generally increased emissions in Indochina and decreased fluxes in Indonesia during intense fire events related to El Niño years, (iv) a significant flux reduction during the major bushfires in Australia, and (v) flux increases during the devastating fires in southern Europe in 2007.

- Changes in fire seasonal patterns are suggested, in particular in southeast Asia and Africa. In southeast Asia, the seasonal amplitude is reduced after inversion, with enhanced emissions due to aboveground vegetation burning in March and weaker emissions due to Indonesian peat burning in August. The inversion suggests generally increased fluxes due to agricultural fires over Africa and decreased emission maxima due to natural fires.

- Significant reductions in isoprene fluxes are inferred in tropical ecosystems (30-40\% in Amazonia and northern Africa), suggesting overestimated basal emission rates in these areas. The top-down fluxes generally increase over Eurasia, especially during heat waves in summer (e.g., western Russia in 2010), suggesting a possibly stronger emission response to high temperatures than currently assumed.

- The inversion suggests large isoprene emission increases (up to $100 \%$ locally) over areas most affected by the soil moisture stress parameterization in MEGAN, in particular in southern Africa and southern Australia. The inferred isoprene increments present a strong interannual correlation with $1 / \gamma_{\mathrm{SM}}$, i.e., the factor by which isoprene emissions are reduced due to soil moisture stress in MEGAN $(r \geq 0.7)$, indicating that the soil moisture parameterization leads to overly decreased isoprene fluxes.

- The isoprene emission trends are found to be often enhanced after inversion. Positive trends in top-down isoprene emissions are inferred in Siberia $\left(4.2 \%\right.$ year $\left.^{-1}\right)$ and eastern Europe ( $3.3 \%$ year $^{-1}$ ), likely reflecting forest expansion and the warming trend. Negative trends are derived in Amazonia $\left(-2.1 \%\right.$ year $\left.^{-1}\right)$, south China $\left(-1 \%\right.$ year $\left.^{-1}\right)$, the United States $\left(-3.7 \%\right.$ year $\left.^{-1}\right)$, and western Europe $\left(-3.9 \%\right.$ year $\left.^{-1}\right)$. The top-down trends should be considered with caution due to possible drifts in the satellite data. In several instances, however, they are supported by independent evidence from literature studies. Trends in $\mathrm{NO}_{x}$ emissions may play a significant role given their possibly large influence on formaldehyde yields, which remain imperfectly characterized and deserve more attention, especially at low $\mathrm{NO}_{x}$. 
For simplicity and to avoid excessive computational costs, a detailed error assessment of the a posteriori emission estimates is not addressed in this work. Nevertheless, sensitivity inversions conducted in an earlier study, also based on OMI columns for 2010, have shown that the inferred fluxes were generally weakly dependent on the choice of key model and inversion parameters and lay within $7 \%$ of the standard inversion results (Stavrakou et al., 2015). Recent developments in the representation of vertical profiles of smoke released by open fires (Sofiev et al., 2013), in the partitioning of burned biomass into emitted trace gases (Akagi et al., 2011), and in the spatiotemporal variability of emission factors (van Leeuwen and van der Werf, 2011; van Leeuwen et al., 2013) indicate additional sources of uncertainty that could impact the top-down fluxes and should therefore be carefully assessed in future studies.

\section{Data availability}

The OMI HCHO column data are publicly accessible at http://h2co.aeronomie.be (De Smedt and Van Roozendael, 2016). The OMI-based inventories are freely available at the GlobEmission web portal (http://www.globemission.eu; Stavrakou et al., 2016b) and at the BIRA-IASB emission portal (http://emissions.aeronomie.be; Stavrakou et al., 2016c). The MEGAN-MOHYCAN bottom-up inventory is also available at http://emissions.aeronomie.be.

\section{The Supplement related to this article is available online at doi:10.5194/acp-16-10133-2016-supplement.}

Acknowledgements. This research was supported by the Belgian Science Policy Office through the PRODEX projects ACROSAT, by the European Space Agency (ESA) through the GlobEmission DUE project (2011-2016), and by the MARCOPOLO project (2014-2016) funded by the European Commission within the Seventh Framework Programme (grant agreement: 606593).

Edited by: A. Pozzer

Reviewed by: two anonymous referees

\section{References}

Akagi, S. K., Yokelson, R. J., Wiedinmyer, C., Alvarado, M. J., Reid, J. S., Karl, T., Crounse, J. D., and Wennberg, P. O.: Emission factors for open and domestic biomass burning for use in atmospheric models, Atmos. Chem. Phys., 11, 4039-4072, doi:10.5194/acp-11-4039-2011, 2011

Alencar, A., Asner, G. P., Knapp, D. and Zarin, D.: Temporal variability of forest fires in eastern Amazonia, Ecol. Appl., 21, $2397-$ 2412, doi:10.1890/10-1168.1, 2011.
Alves, E. G., Jardine, K., Tota, J., Jardine, A., Yãnez-Serrano, A. M., Karl, T., Tavares, J., Nelson, B., Gu, D., Stavrakou, T., Martin, S., Artaxo, P., Manzi, A., and Guenther, A.: Seasonality of isoprenoid emissions from a primary rainforest in central Amazonia, Atmos. Chem. Phys., 16, 3903-3925, doi:10.5194/acp-163903-2016, 2016.

Andela, N. and van der Werf, G. R.: Recent trends in African fires driven by cropland expansion and El Niño to La Niña transition, Nature Climate Change, 4, 791-795, doi:10.1038/nclimate2313, 2014.

Andela, N., Kaiser, J. W., Heil, A., van Leeuwen, T. T., van der Werf, G. R., Wooster, M. J., Remy, S., and Schultz, M. G.: Assessment of the Global Fire Assimilation System (GFASv1), MACC-II project (Monitoring Atmospheric Composition and Climate - Interim Implementation, deliverable D31.2, ECMWF Technical Memorandum, No. 702, 2013.

Anderson, L. O., Aragão, L. E., Gloor, M., Arai, E., Adami, M., Saatchi, S., Malhi, Y., Shimabukuro, Y. E., Barlow, J., Berenguer, E., and Duarte, V.: Disentangling the contribution of multiple land covers to fires-mediated carbon emissions in Amazonia during the 2010 drought, Global Biogeochem. Cy., 29, 1739-1753, doi:10.1002/2014GB005008, 2015.

Andreae, M., Artaxo, P., Brandao, C., Carswell, F., Ciccioli, P., Da Costa, A., Culf, A., Esteves, J., Gash, J., Grace, J., Kabat, P., Lelieveld, J., Malhi, Y., Manzi, A. O., Meixner, F. X., Nobre, A. D., Nobre, C., Ruivo, M. d. L. P., Silva-Dias, M. A., Stefani, P., Valentini, R., von Jouanne, J., and Waterloo, M. J.: Biogeochemical cycling of carbon, water, energy, trace gases, and aerosols in Amazonia: The LBA-EUSTACH experiments, J. Geophys. Res., 107, 8066, doi:10.1029/2001JD000524, 2002.

Andreae, M. O. and Merlet, P.: Emission of trace gases and aerosols from biomass burning, Global Biogeochem. Cy., 15, 955-966, doi:10.1029/2000GB001382, 2001.

Arneth, A., Niinemets, Ü., Pressley, S., Bäck, J., Hari, P., Karl, T., Noe, S., Prentice, I. C., Serça, D., Hickler, T., Wolf, A., and Smith, B.: Process-based estimates of terrestrial ecosystem isoprene emissions: incorporating the effects of a direct $\mathrm{CO}_{2}$-isoprene interaction, Atmos. Chem. Phys., 7, 31-53, doi:10.5194/acp-7-31-2007, 2007.

Arneth, A., Schurgers, G., Lathiere, J., Duhl, T., Beerling, D. J., Hewitt, C. N., Martin, M., and Guenther, A.: Global terrestrial isoprene emission models: sensitivity to variability in climate and vegetation, Atmos. Chem. Phys., 11, 8037-8052, doi:10.5194/acp-11-8037-2011, 2011.

Ballhorn, U., Siegert, F., Mason, M., and Limin, S.: Derivation of burn scar depths and estimation of carbon emissions with LIDAR in Indonesian peatlands, P. Natl. Acad. Sci. USA, 106, 21213 21218, doi:10.1073/pnas.0906457106, 2009.

Barkley, M. P., Palmer, P. I., Kuhn, U., Kesselmeier, J., Chance, K., Kurosu, T. P., Martin, R. V., Helmig, D., and Guenther, A.: Net ecosystem fluxes of isoprene over tropical South America inferred from Global Ozone Monitoring Experiment (GOME) observations of HCHO columns, J. Geophys. Res., 113, D20304, doi:10.1029/2008JD009863, 2008.

Barkley, M. P., Palmer, P. I., De Smedt, I., Karl, T., Guenther, A., and Van Roozendael, M.: Regulated large-scale annual shutdown of Amazonian isoprene emissions?, Geophys. Res. Lett., 36, L04803, doi:10.1029/2008GL036843, 2009. 
Barkley, M. P., De Smedt, I., Van Roozendael, M., Kurosu, T. P., Chance, K., Arneth, A., Hagberg, D., Guenther, A., Paulot, F., Marais, E., and Mao, J.: Top-down isoprene emissions over tropical South America inferred from SCIAMACHY and OMI formaldehyde columns, J. Geophys. Res., 118, 6849-6868, doi:10.1002/jgrd.50552, 2013.

Barriopedro, D., Fischer, E. M.,Luterbacher, J., Trigo, R. M., and García-Herrera, R.: The hot summer of 2010: Redrawing the temperature record map of Europe, Science, 332, 220-224, 2011.

Bates, K. H., Nguyen, T. B., Teng, A. P., Crounse, J. D., Kjaergaard, H. G., Stoltz, B. M., Seinfeld, J. H., and Wennberg, P. O.: Production and fate of $\mathrm{C}_{4}$ dihydroxycarbonyl compounds from isoprene oxidation, J. Phys. Chem. A, 120, 106-117, 2016.

Bauwens, M., Stavrakou, T., Müller, J.-F., De Smedt, I., and Van Roozendael, M.: Satellite-based isoprene emission estimates (2007-2012) from the GlobEmission project, Proccedings of ACCENT-Plus Symposium, Urbino, 2014.

Bloom, A. A., Worden, J., Jiang, Z., Worden, H., Kurosu, T., Frankenberg, C., and Schimel, D.: Remote-sensing constraints on South America fire traits by Bayesian fusion of atmospheric and surface data, Geophys. Res. Lett., 42, 1268-1274, doi:10.1002/2014GL062584, 2015.

Boersma, K. F., Eskes, H. J., Dirksen, R. J., van der A, R. J., Veefkind, J. P., Stammes, P., Huijnen, V., Kleipool, Q. L., Sneep, M., Claas, J., Leitão, J., Richter, A., Zhou, Y., and Brunner, D.: An improved tropospheric $\mathrm{NO}_{2}$ column retrieval algorithm for the Ozone Monitoring Instrument, Atmos. Meas. Tech., 4, 19051928, doi:10.5194/amt-4-1905-2011, 2011.

Chance, K., Palmer, P. I., Spurr, R. J. D., Martin, R. V., Kurosu, T., and Jacob, D. J.: Satellite observations of formaldehyde over North America from GOME, Geophys. Res. Lett., 27, 34613464, 2000.

Chang, D. and Song, Y.: Estimates of biomass burning emissions in tropical Asia based on satellite-derived data, Atmos. Chem. Phys., 10, 2335-2351, doi:10.5194/acp-10-2335-2010, 2010.

Chen, Y., Morton, D. C., Jin, Y., Collatz, G. J., Kasibhatla, P. S., Werf, G. R. van der, DeFries, R. S., and Randerson, J. T.: Longterm trends and interannual variability of forest, savanna and agricultural fires in South America, Carbon Manag., 4, 617-638, doi:10.4155/cmt.13.61, 2013.

Chevallier, F., Fortems, A., Bousquet, P., Pison, I., Szopa, S., Devaux, M., and Hauglustaine, D. A.: African CO emissions between years 2000 and 2006 as estimated from MOPITT observations, Biogeosciences, 6, 103-111, doi:10.5194/bg-6-103-2009, 2009.

Ciccioli, P., Brancaleoni, E., Frattoni, M., Kuhn, U., Kesselmeier, J., Dindorf, T., de Araújo, A., Nobre, A., Stefani, P., and Valentini, R.: Fluxes of isoprenoid compounds over the tropical rainforest near Manaus during the dry season and their implications in the ecosystem carbon budget and in the atmospheric chemistry processes, in: Integrated Land Ecosystem-Atmosphere Processes Study (ILEAPS) International Open Science Conference 2003, 48-53, Finnish Association for Aerosol Research, 2003.

Coumou, D. and Rahmstorf, S.: A decade of weather extremes, Nature Climate Change, 2, 491-496, doi:10.1038/nclimate1452, 2012.

De Smedt, I. and Van Roozendael, M.: Tropospheric Formaldehyde, Royal Belgian Institute for Space Aeronomy (BIRA-
IASB), available at: http://h2co.aeronomie.be, last access: $8 \mathrm{Au}-$ gust 2016.

De Smedt, I., Stavrakou, T., Hendrick, F., Danckaert, T., Vlemmix, T., Pinardi, G., Theys, N., Lerot, C., Gielen, C., Vigouroux, C., Hermans, C., Fayt, C., Veefkind, P., Müller, J.-F., and Van Roozendael, M.: Diurnal, seasonal and long-term variations of global formaldehyde columns inferred from combined OMI and GOME-2 observations, Atmos. Chem. Phys., 15, 12519-12545, doi:10.5194/acp-15-12519-2015, 2015.

Ding, J., van der A, R. J., Mijling, B., Levelt, P. F., and Hao, N.: $\mathrm{NO}_{x}$ emission estimates during the 2014 Youth Olympic Games in Nanjing, Atmos. Chem. Phys., 15, 9399-9412, doi:10.5194/acp-15-9399-2015, 2015.

Fanin, T. and van der Werf, G. R.: Relationships between burned area, forest cover loss, and land cover change in the Brazilian Amazon based on satellite data, Biogeosciences, 12, 6033-6043, doi:10.5194/bg-12-6033-2015, 2015.

Founda, D. and Giannakopoulos, C.: The exceptionally hot summer of 2007 in Athens, Greece - A typical summer in the future climate?, Global Planet. Change, 67, 227-236, 2009.

Friedl, M. A., Sulla-Menashe, D., Tan, B., Schneider, A., Ramankutty, N., Sibley, A., and Huang, X.: MODIS Collection 5 global land cover: Algorithm refinements and characterization of new datasets, 2001-2012, Collection 5.1 IGBP Land Cover, Boston University, Boston, MA, USA, 2010.

Giglio, L., Randerson, J. T., and Werf, G. R.: Analysis of daily, monthly, and annual burned area using the fourth-generation global fire emissions database (GFED4), J. Geophys. Res., 118, 317-328, doi:10.1002/jgrg.20042, 2013.

Greenberg, J. P., Guenther, A. B., Pétron, G., Wiedinmyer, C., Vega, O., Gatti, L. V., Tota, J., and Fisch, G.: Biogenic VOC emissions from forested Amazonian landscapes, Glob. Change Biol., 10, 651-662, doi:10.1111/j.1365-2486.2004.00758.x, 2004.

Guenther, A., Hewitt, C. N., Erickson, D., Fall, R., Geron, C., Graedel, T., Harley, P., Klinger, L., Lerdau, M., McKay, W. A., Pierce, T., Scholes, B., Steinbrecher, R., Tallamraju, R., Taylor, J., and Zimmerman, P.: A global model of natural volatile organic compound emissions, J. Geophys. Res., 100, 8873-8892, 1995.

Guenther, A., Karl, T., Harley, P., Wiedinmyer, C., Palmer, P. I., and Geron, C.: Estimates of global terrestrial isoprene emissions using MEGAN (Model of Emissions of Gases and Aerosols from Nature), Atmos. Chem. Phys., 6, 3181-3210, doi:10.5194/acp-63181-2006, 2006.

Guenther, A. B., Jiang, X., Heald, C. L., Sakulyanontvittaya, T., Duhl, T., Emmons, L. K., and Wang, X.: The Model of Emissions of Gases and Aerosols from Nature version 2.1 (MEGAN2.1): an extended and updated framework for modeling biogenic emissions, Geosci. Model Dev., 5, 1471-1492, doi:10.5194/gmd-51471-2012, 2012.

Hartmann, D. L., Klein Tank, A .M. G., Rusticucci, M., Alexander, L. V., Brönnimann, S., Charabi, Y., Dentener, F. J., Dlugokencky, E. J., Easterling, D. R., Kaplan, A., Soden, B. J., Thorne, P. W., Wild, M., and Zhai, P. M.: Observations: Atmosphere and Surface, in: Climate Change 2013: The Physical Science Basis. Contribution of Working Group I to the Fifth Assessment Report of the Intergovernmental Panel on Climate Change, edited by: Stocker, T. F., Qin, D., Plattner, G.-K., Tignor, M., Allen, S. K., Boschung, J., Nauels, A., Xia, Y., Bex, V., and Midgley P. M., 
Cambridge University Press, Cambridge, United Kingdom and New York, NY, USA, 2013.

Helmig, D., Balsley, B., Davis, K., Kuck, L. R., Jensen, M., Bognar, J., Smith, T., Arrieta, R. V., Rodriguez, R., and Birks, J. W.: Vertical profiling and determination of landscape fluxes of biogenic nonmethane hydrocarbons within the planetary boundary layer in the Peruvian Amazon, J. Geophys. Res., 103, 25519-25532, 1998.

Hilker, T., Lyapustin, A. I., Tucker, C. J., Hall,F. G., Myneni, R. B., Wang, Y., Bid, J., Mendes, Y., de Mourae, and Sellers, P. J.: Vegetation dynamics and rainfall sensitivity of the Amazon, P. Natl. Acad. Sci., 111, 16041-16046, doi:10.1073/pnas.1404870111, 2014.

Huang, X., Song, Y., Li, M., Li, J., and Zhu, T.: Harvest season, high polluted season in East China, Environ. Res. Lett., 7, 044033, doi:10.1088/1748-9326/7/4/044033, 2012.

Hurtt, G. C., Chini, L. P., Frolking, S., Betts, R. A., Feddema, J., Fischer, G., Fisk, J. P., Hibbard, K., Houghton, R. A., Janetos, A., Jones, C. D., Kindermann, T., Kinoshita, T., Goldewijk, K. K., Riahi, K., Shevliakova, E., Smith, S., Stehfest, E., Thomson, A., Thornton, P., van Vuuren, D. P., and Wang, Y. P.: Harmonization of land-use scenarios for the period 1500-2100: 600 years of global annual land-use transitions, wood harvest, and resulting secondary lands, Climatic Change, 109, 117-161, doi:10.1007/s10584-011-0153-2, 2011.

Hyer, E. J. and Reid, J. S.: Baseline uncertainties in biomass burning emission models resulting from spatial error in satellite active fire location data, Geophys. Res. Lett., 36, L05802, doi:10.1029/2008GL036767, 2009.

Jaeglé, L., Steinberger, L., Randall, M., and Chance, L.: Global Partitioning of $\mathrm{NO}_{x}$ Sources Using Satellite Observations: Relative Roles of Fossil Fuel Combustion, Biomass Burning and Soil Emissions, Faraday Discuss., 130, 407-423, doi:10.1039/B502128F, 2005.

Jha, M. K.: Natural and Anthropogenic Disasters: Vulnerability, Preparedness and Mitigation, ISBN: 978-90-481-2497-8, Springer, P.O. Box 17, 3300 AA Dordrecht, the Netherlands, 2010.

Joiner, J., Yoshida, Y., Guanter, L., and Middleton, E. M.: New methods for retrieval of chlorophyll red fluorescence from hyperspectral satellite instruments: simulations and application to GOME-2 and SCIAMACHY, Atmos. Meas. Tech. Discuss., doi:10.5194/amt-2015-387, in review, 2016.

Justice, C., Townshend, J., Vermote, E., Masuoka, E., Wolfe, R., Saleous, N., Roy, D., and Morisette, J.: An overview of MODIS Land data processing and product status, Remote Sens. Environ., 83, 3-15, doi:10.1016/S0034-4257(02)00084-6, 2002.

Kaiser, J. W., Heil, A., Andreae, M. O., Benedetti, A., Chubarova, N., Jones, L., Morcrette, J.-J., Razinger, M., Schultz, M. G., Suttie, M., and van der Werf, G. R.: Biomass burning emissions estimated with a global fire assimilation system based on observed fire radiative power, Biogeosciences, 9, 527-554, doi:10.5194/bg-9-527-2012, 2012.

Karki, S.: Community involvement in and management of forest fires in South East Asia, Project FireFight South East Asia, P.O. 6596 JKPWB, Jakarta, Indonesia, 2002.

Karl, T., Guenther, A., Yokelson, R. J., Greenberg, J., Potosnak, M., Blake, D. R., and Artaxo, P.: The tropical forest and fire emissions experiment: Emission, chemistry, and transport of biogenic volatile organic compounds in the lower atmosphere over Amazonia, J. Geophys. Res.-Atmos., 112, D18302, doi:10.1029/2007JD008539, 2007.

Karl, T., Guenther, A., Turnipseed, A., Tyndall, G., Artaxo, P., and Martin, S.: Rapid formation of isoprene photo-oxidation products observed in Amazonia, Atmos. Chem. Phys., 9, 7753-7767, doi:10.5194/acp-9-7753-2009, 2009.

Kharol, S. K., Martin, R. V., Philip, S., Boys, B., Lamsal, L. N., Jerrett, M., Brauer, M., Crounse, D. L., McLinden, C., and Burnett, R. T.: Assessment of the magnitude and recent trends in satellitederived ground-level nitrogen dioxide over North America, Atmos. Environ., 118, 236-245, 2015.

Konovalov, I. B., Beekmann, M., Kuznetsova, I. N., Yurova, A., and Zvyagintsev, A. M.: Atmospheric impacts of the 2010 Russian wildfires: integrating modelling and measurements of an extreme air pollution episode in the Moscow region, Atmos. Chem. Phys., 11, 10031-10056, doi:10.5194/acp-11-10031-2011, 2011.

Kopacz, M., Jacob, D. J., Fisher, J. A., Logan, J. A., Zhang, L., Megretskaia, I. A., Yantosca, R. M., Singh, K., Henze, D. K., Burrows, J. P., Buchwitz, M., Khlystova, I., McMillan, W. W., Gille, J. C., Edwards, D. P., Eldering, A., Thouret, V., and Nedelec, P.: Global estimates of CO sources with high resolution by adjoint inversion of multiple satellite datasets (MOPITT, AIRS, SCIAMACHY, TES), Atmos. Chem. Phys., 10, 855-876, doi:10.5194/acp-10-855-2010, 2010.

Kramshøj, M., Vedel-Petersen, I., Schollert, M., Rinna, Å., Nymand, J., Ro-Poulsen, H., and Rinna, R.: Large increases in Arctic biogenic volatile emissions are a direct effect of warming, Nat. Geosci., 9, 349-352, 2016.

Krol, M., Peters, W., Hooghiemstra, P., George, M., Clerbaux, C., Hurtmans, D., McInerney, D., Sedano, F., Bergamaschi, P., El Hajj, M., Kaiser, J. W., Fisher, D., Yershov, V., and Muller, J.-P.: How much CO was emitted by the 2010 fires around Moscow?, Atmos. Chem. Phys., 13, 4737-4747, doi:10.5194/acp-13-47372013, 2013.

Kuhn, U., Andreae, M. O., Ammann, C., Araújo, A. C., Brancaleoni, E., Ciccioli, P., Dindorf, T., Frattoni, M., Gatti, L. V., Ganzeveld, L., Kruijt, B., Lelieveld, J., Lloyd, J., Meixner, F. X., Nobre, A. D., Pöschl, U., Spirig, C., Stefani, P., Thielmann, A., Valentini, R., and Kesselmeier, J.: Isoprene and monoterpene fluxes from Central Amazonian rainforest inferred from towerbased and airborne measurements, and implications on the atmospheric chemistry and the local carbon budget, Atmos. Chem. Phys., 7, 2855-2879, doi:10.5194/acp-7-2855-2007, 2007.

Kurokawa, J., Ohara, T., Morikawa, T., Hanayama, S., JanssensMaenhout, G., Fukui, T., Kawashima, K., and Akimoto, H.: Emissions of air pollutants and greenhouse gases over Asian regions during 2000-2008: Regional Emission inventory in ASia (REAS) version 2, Atmos. Chem. Phys., 13, 11019-11058, doi:10.5194/acp-13-11019-2013, 2013.

Langford, B., Misztal, P. K., Nemitz, E., Davison, B., Helfter, C., Pugh, T. A. M., MacKenzie, A. R., Lim, S. F., and Hewitt, C. N.: Fluxes and concentrations of volatile organic compounds from a South-East Asian tropical rainforest, Atmos. Chem. Phys., 10, 8391-8412, doi:10.5194/acp-10-8391-2010, 2010.

Magi, B. I., Rabin, S., Shevliakova, E., and Pacala, S.: Separating agricultural and non-agricultural fire seasonality at regional scales, Biogeosciences, 9, 3003-3012, doi:10.5194/bg-9-30032012, 2012. 
Marais, E. A., Jacob, D. J., Kurosu, T. P., Chance, K., Murphy, J. G., Reeves, C., Mills, G., Casadio, S., Millet, D. B., Barkley, M. P., Paulot, F., and Mao, J.: Isoprene emissions in Africa inferred from OMI observations of formaldehyde columns, Atmos. Chem. Phys., 12, 6219-6235, doi:10.5194/acp-12-62192012, 2012.

Marais, E. A., Jacob, D. J., Guenther, A., Chance, K., Kurosu, T. P., Murphy, J. G., Reeves, C. E., and Pye, H. O. T.: Improved model of isoprene emissions in Africa using Ozone Monitoring Instrument (OMI) satellite observations of formaldehyde: implications for oxidants and particulate matter, Atmos. Chem. Phys., 14, 7693-7703, doi:10.5194/acp-14-7693-2014, 2014.

Mijling, B., and van der A, R. J.: Using daily satellite observations to estimate emissions of short-lived air pollutants on a mesoscopic scale, 117, D17302, doi:10.1029/2012JD017817, 2012.

Millet, D. B., Jacob, D. J., Boersma, K. F., Fu, T.-M., Kurosu, T. P., Chance, K., Heald, C. L. and Guenther, A.: Spatial distribution of isoprene emissions from North America derived from formaldehyde column measurements by the OMI satellite sensor, J. Geophys. Res.-Atmos., 113, D02307, doi:10.1029/2007JD008950, 2008.

Mitchell, T. D. and Jones, P. D.: An improved method of constructing a database of monthly climate observations and associated high-resolution grids, Int. J. Climatol., 25, 693-712, doi:10.1002/joc.1181, 2005.

Müller, J.-F. and Stavrakou, T.: Inversion of $\mathrm{CO}$ and $\mathrm{NO}_{x}$ emissions using the adjoint of the IMAGES model, Atmos. Chem. Phys., 5, 1157-1186, doi:10.5194/acp-5-1157-2005, 2005.

Müller, J.-F., Stavrakou, T., Wallens, S., De Smedt, I., Van Roozendael, M., Potosnak, M. J., Rinne, J., Munger, B., Goldstein, A., and Guenther, A. B.: Global isoprene emissions estimated using MEGAN, ECMWF analyses and a detailed canopy environment model, Atmos. Chem. Phys., 8, 1329-1341, doi:10.5194/acp-81329-2008, 2008.

Nepstad, D., McGrath, D., Stickler, C., Alencar, A., Azevedo, A., Swette, B., Bezerra, T., DiGiano, M., Shimada, J., da Motta R. S., Armijo, E., Castello, L., Brando, P., Hansen, M. C., McGrath-Horn, M., Carvalho, O., and Hess, L.: Slowing Amazon deforestation through public policy and interventions in beef and soy supply chains, Science, 344, 1118-1123, doi:10.1126/science.1248525, 2014.

Niinemets, Ü., Tenhunen, J., Harley, P., and Steinbrecher, R.: A model of isoprene emission based on energetic requirements for isoprene synthesis and leaf photosynthetic properties for Liquidambar and Quercus, Plant Cell Environ., 22, 1319-1335, doi:10.1046/j.1365-3040.1999.00505.x, 1999.

Palmer, P. I., Jacob, D. J., Fiore, A., Chance, K. V., Martin, R. V., Kurosu, T. P., Bey, I., Yantosca, R., Fiore, A., and Li, Q.: Mapping isoprene emissions over North America using formaldehyde column observations from space, J. Geophys. Res., 108, 4180, doi:10.1029/2002JD002153, 2003.

Palmer, P. I., Abbot, D. S., Fu, T.-M., Jacob, D. J., Chance, K., Kurosu, T. P., Guenther, A., Wiedinmyer, C., Stanton, J. C., Pilling, M. J., Pressley, S. N., Lamb, B., and Sumner, A. L.: Quantifying the seasonal and interannual variability of North American isoprene emissions using satellite observations of the formaldehyde column, J. Geophys. Res., 111, D12315, doi:10.1029/2005JD006689, 2006.
Peeters, J., Müller, J.-F., Stavrakou, T., and Nguyen, S. V.: Hydroxyl radical recycling in isoprene oxidation driven by hydrogen bonding and hydrogen tunneling: the upgraded LIM1 mechanism, J. Phys. Chem. A, 118, 8625-8643, doi:10.1021/jp5033146, 2014.

Pétron, G., Granier, G., Khattotov, B., Yudin, V., Lamarque, J.-F., Emmons, L., Gille, J., and Edwards, D. P.: Monthly CO surface sources inventory based on the 2000-2001 MOPITT satellite data, Geophys. Res. Lett., 31, L21107, doi:10.1029/2004GL020560, 2004.

Potosnak, M. J., Baker, B. M., LeStourgeon, L., Disher, S. M., Griffin, K. L., Bret-Harte, M. S., and Starr, G.: Isoprene emissions from a tundra ecosystem, Biogeosciences, 10, 871-889, doi:10.5194/bg-10-871-2013, 2013.

Ramankutty, N. and Foley, J. A.: Estimating historical changes in global land cover : croplands from 1700 to 1992, Global Biogeochem. Cy., 13, 997-1027, 1999.

Randerson, J. T., Chen, Y., van der Werf, G. R., Rogers, B. M., and Morton, D. C.: Global burned area and biomass burning emissions from small fires, J. Geophys. Res., 117, G04012, doi:10.1029/2012JG002128, 2012.

Reddington, C., Yoshioka, M., Balasubramanian, R., Ridley, D., Toh, Y., Arnold, S., and Spracklen, D.: Contribution of vegetation and peat fires to particulate air pollution in Southeast Asia, Environ. Res. Lett., 9, 094006, doi:10.1088/1748-9326/9/9/094006, 2014.

Reuter, M., Buchwitz, M., Hilboll, A., Richter, A., Schneising, O., Hilker, M., Heymann, J. Bovensmann, H., and Burrows, J. P.: Decreasing emissions of $\mathrm{NO}_{x}$ relative to $\mathrm{CO}_{2}$ in East Asia inferred from satellite observations, Nature Geosci., 7, 792-795, 2014.

Richter, A., Begoin, M., Hilboll, A., and Burrows, J. P.: An improved $\mathrm{NO}_{2}$ retrieval for the GOME-2 satellite instrument, Atmos. Meas. Tech., 4, 1147-1159, doi:10.5194/amt-4-1147-2011, 2011.

Rienecker, M. M., Suarez, M. J., Gelaro, R., Todling, R., Bacmeister, J., Liu, E., Bosilovich, M. G., Schubert, S. D., Takacs, L., Kim, G.-K., Bloom, S., Junye, C., Collins, D., Conaty, A., da Silva, A., Gu, W., Joiner, J., Koster, R. D., Lucchesi, R., Molod, A., Owens, T., Pawson, S., Pegion, P., Redder, C. R., Reichle, R., Robertson, F. R., Ruddick, A. G., Sienkiewicz, M., and Woollen, J.: MERRA: NASA modern-era retrospective analysis for research and applications, J. Climate, 24, 3624-3648, 2011.

Rinne, H., Guenther, A., Greenberg, J., and Harley, P.: Isoprene and monoterpene fluxes measured above Amazonian rainforest and their dependence on light and temperature, Atmos. Environ., 36, 2421-2426, doi:10.1016/S1352-2310(01)00523-4, 2002.

Rizzo, L. V., Artaxo, P., Karl, T., Guenther, A. B., and Greenberg, $\mathrm{J}$.: Aerosol properties, in-canopy gradients, turbulent fluxes and VOC concentrations at a pristine forest site in Amazonia, Atmos. Environ., 44, 503-511, doi:10.1016/j.atmosenv.2009.11.002, 2010.

Romero-Ruiz, M., Etter, A., Sarmiento, A., and Tansey, K.: Spatial and temporal variability of fires in relation to ecosystems, land tenure and rainfall in savannas of northern South America, Glob. Change Biol., 16, 2013-2023, doi:10.1111/j.13652486.2009.02081.x, 2010.

Russell, A. R., Valin, L. C., and Cohen, R. C.: Trends in $\mathrm{OMI} \mathrm{NO}_{2}$ observations over the United States: effects of emission control technology and the economic recession, Atmos. Chem. Phys., 12, 12197-12209, doi:10.5194/acp-12-12197-2012, 2012. 
Schultz, M. G., Backman, L., Balkanski, Y., et al.: REanalysis of the TROpospheric chemical composition over the past 40 years (RETRO): A long-term global modeling study of tropospheric chemistry, Jülich/Hamburg, Germany, 48/2007 report on Earth System Science of the Max Planck Institute for Meteorology, Hamburg, Germany, ISSN 1614-1199, 2007.

Schultz, M. G., Heil, A., Hoelzemann, J. J., Spessa, A., Thonicke, K., Goldammer, J. G., Held, A. C., Pereira, J., and van het Bolscher, M.: Global wildland fire emissions from 1960 to 2000, Global Biogeochem. Cy., 22, GB2002, doi:10.1029/2007GB003031, 2008.

Seco, R., Karl, T., Guenther, A., Hosman, K. P., Pallardy, S. G., Gu, L., Geron, C., Harley, P., and Kim, S.: Ecosystem-scale volatile organic compound fluxes during an extreme drought in a broadleaf temperate forest of the Missouri Ozarks (central USA), Glob. Change Biol., 21, 3657-3674, 2015.

Simon, E., Meixner, F. X., Rummel, U., Ganzeveld, L., Ammann, C., and Kesselmeier, J.: Coupled carbon-water exchange of the Amazon rain forest, II. Comparison of predicted and observed seasonal exchange of energy, $\mathrm{CO}_{2}$, isoprene and ozone at a remote site in Rondônia, Biogeosciences, 2, 255-275, doi:10.5194/bg-2-255-2005, 2005.

Sindelarova, K., Granier, C., Bouarar, I., Guenther, A., Tilmes, S., Stavrakou, T., Müller, J.-F., Kuhn, U., Stefani, P., and Knorr, W.: Global data set of biogenic VOC emissions calculated by the MEGAN model over the last 30 years, Atmos. Chem. Phys., 14, 9317-9341, doi:10.5194/acp-14-9317-2014, 2014.

Sitch, S., Smith, B., Prentice, I. C., Arneth, A., Bondeau, A., Cramer, W., Kaplan, J., Levis, S., Lucht, W., Sykes, M. T., Thonicke, K., and Venevsky, S.: Evaluation of ecosystem dynamics, plant geography and terrestrial carbon cycling in the LPJ dynamic global vegetation model, Glob. Change Biol., 9, 161-185, doi:10.1046/j.1365-2486.2003.00569.x, 2003.

Soares, J., Sofiev, M., and Hakkalainen, J.: Uncertainties in wildland fire emissions in AQMEII phase 2 case study, Atmos. Environ., 115, 361-370, 2015.

Sofiev, M., Vankevich, R., Ermakova, T., and Hakkarainen, J.: Global mapping of maximum emission heights and resulting vertical profiles of wildfire emissions, Atmos. Chem. Phys., 13, 7039-7052, doi:10.5194/acp-13-7039-2013, 2013.

Stavrakou, T., Müller, J.-F., Boersma, K. F., De Smedt, I., and van der A, R. J. : Assessing the distribution and growth rates of $\mathrm{NO}_{x}$ emission sources by inverting a 10-year record of $\mathrm{NO}_{2}$ satellite columns, Geophys. Res. Lett., 35, L10801, doi:10.1029/2008GL033521, 2008.

Stavrakou, T., Müller, J.-F., De Smedt, I., Van Roozendael, M., van der Werf, G. R., Giglio, L., and Guenther, A.: Evaluating the performance of pyrogenic and biogenic emission inventories against one decade of space-based formaldehyde columns, Atmos. Chem. Phys., 9, 1037-1060, doi:10.5194/acp-9-1037-2009, 2009a.

Stavrakou, T., Müller, J.-F., De Smedt, I., Van Roozendael, M., van der Werf, G. R., Giglio, L., and Guenther, A.: Global emissions of non-methane hydrocarbons deduced from SCIAMACHY formaldehyde columns through 2003-2006, Atmos. Chem. Phys., 9, 3663-3679, doi:10.5194/acp-9-3663-2009, 2009b.

Stavrakou, T., Peeters, J., and Müller, J.-F.: Improved global modelling of $\mathrm{HO}_{x}$ recycling in isoprene oxidation: evaluation against the GABRIEL and INTEX-A aircraft campaign measurements,
Atmos. Chem. Phys., 10, 9863-9878, doi:10.5194/acp-10-98632010, 2010.

Stavrakou, T., Müller, J.-F., Boersma, K. F., van der A, R. J., Kurokawa, J., Ohara, T., and Zhang, Q.: Key chemical $\mathrm{NO}_{x}$ sink uncertainties and how they influence top-down emissions of nitrogen oxides, Atmos. Chem. Phys., 13, 9057-9082, doi:10.5194/acp-13-9057-2013, 2013.

Stavrakou, T., Müller, J.-F., Bauwens, M., De Smedt, I., Van Roozendael, M., Guenther, A., Wild, M., and Xia, X.: Isoprene emissions over Asia 1979-2012: impact of climate and land-use changes, Atmos. Chem. Phys., 14, 4587-4605, doi:10.5194/acp14-4587-2014, 2014.

Stavrakou, T., Müller, J.-F., Bauwens, M., De Smedt, I., Van Roozendael, M., De Mazière, M., Vigouroux, C., Hendrick, F., George, M., Clerbaux, C., Coheur, P.-F., and Guenther, A.: How consistent are top-down hydrocarbon emissions based on formaldehyde observations from GOME-2 and OMI?, Atmos. Chem. Phys., 15, 11861-11884, doi:10.5194/acp-15-118612015, 2015.

Stavrakou, T., Müller, J.-F., Bauwens, M., De Smedt, Lerot, C., Van Roozendael, M., Coheur, P.-F., Clerbaux, C., Boersma, K. F., van der A, R., and Song, Y.: Substantial underestimation of postharvest burning emissions in the North China Plain revealed by multi-species space observations, Sci. Rep., accepted, 2016a.

Stavrakou, T., Bauwens, M., and Müller, J.-F.: Satellite-derived isoprene and fire emissions based on OMI HCHO observations, Royal Belgian Institute for Space Aeronomy (BIRA-IASB), available at: http://www.globemission.eu, last access: 8 August $2016 b$.

Stavrakou, T., Bauwens, M., and Müller, J.-F.: Bottom-up and satellite-derived inventories, Royal Belgian Institute for Space Aeronomy (BIRA-IASB), available at: http://emissions. aeronomie.be, last access: 8 August 2016c.

Steffen, W., Hughes, L., and Pearce, A.: The heat is on: climate change, extreme heat and bushfires in Western Australia, Climate Council of Australia Ltd, 2015.

Stohl, A., Berg, T., Burkhart, J. F., Fjǽraa, A. M., Forster, C., Herber, A., Hov, Ø., Lunder, C., McMillan, W. W., Oltmans, S., Shiobara, M., Simpson, D., Solberg, S., Stebel, K., Ström, J., Tørseth, K., Treffeisen, R., Virkkunen, K., and Yttri, K. E.: Arctic smoke - record high air pollution levels in the European Arctic due to agricultural fires in Eastern Europe in spring 2006, Atmos. Chem. Phys., 7, 511-534, doi:10.5194/acp-7-511-2007, 2007.

Tang, W., Cohan, D. S., Lamsal, L. N., Xiao, X., and Zhou, W.: Inverse modeling of Texas $\mathrm{NO}_{x}$ emissions using space-based and ground-based NO2 observations, Atmos. Chem. Phys., 13, 11005-11018, doi:10.5194/acp-13-11005-2013, 2013.

Turquety, S., Hurtmans, D., Hadji-Lazaro, J., Coheur, P.-F., Clerbaux, C., Josset, D., and Tsamalis, C.: Tracking the emission and transport of pollution from wildfires using the IASI CO retrievals: analysis of the summer 2007 Greek fires, Atmos. Chem. Phys., 9, 4897-4913, doi:10.5194/acp-9-4897-2009, 2009.

van der Molen, M. K., de Jeu, R. A. M., Wagner, W., van der Velde, I. R., Kolari, P., Kurbatova, J., Varlagin, A., Maximov, T. C., Kononov, A. V., Ohta, T., Kotani, A., Krol, M. C., and Peters, W.: The effect of assimilating satellite-derived soil moisture data in SiBCASA on simulated carbon fluxes in Boreal Eurasia, Hydrol. Earth Syst. Sci., 20, 605-624, doi:10.5194/hess-20-6052016, 2016. 
van der Werf, G. R., Randerson, J. T., Giglio, L., Collatz, G. J., Mu, M., Kasibhatla, P. S., Morton, D. C., DeFries, R. S., Jin, Y., and van Leeuwen, T. T.: Global fire emissions and the contribution of deforestation, savanna, forest, agricultural, and peat fires (19972009), Atmos. Chem. Phys., 10, 11707-11735, doi:10.5194/acp10-11707-2010, 2010.

van Leeuwen, T. T. and van der Werf, G. R.: Spatial and temporal variability in the ratio of trace gases emitted from biomass burning, Atmos. Chem. Phys., 11, 3611-3629, doi:10.5194/acp11-3611-2011, 2011.

van Leeuwen, T. T., Peters, W., Krol, M. C., and van der Werf, G. R.: Dynamic biomass burning emission factors and their impact on atmospheric CO mixing ratios, J. Geophys. Res., 118, 6797-6815, doi:10.1002/jgrd.50478, 2013.

van Leeuwen, T. T., van der Werf, G. R., Hoffmann, A. A., Detmers, R. G., Rücker, G., French, N. H. F., Archibald, S., Carvalho Jr., J. A., Cook, G. D., de Groot, W. J., Hély, C., Kasischke, E. S., Kloster, S., McCarty, J. L., Pettinari, M. L., Savadogo, P., Alvarado, E. C., Boschetti, L., Manuri, S., Meyer, C. P., Siegert, F., Trollope, L. A., and Trollope, W. S. W.: Biomass burning fuel consumption rates: a field measurement database, Biogeosciences, 11, 7305-7329, doi:10.5194/bg-11-7305-2014, 2014.

Weedon, G. P., Balsano, G., Bellouin, N., Gomes, S., Best, M. J., and Viterbo, P.: The WFDEI meteorological forcing data set: WATCH Forcing Data methodology applied to ERA-Interim reanalysis data, Water Resour. Res., 50, 7505-7514, 2014.

Wiedinmyer, C., Akagi, S. K., Yokelson, R. J., Emmons, L. K., AlSaadi, J. A., Orlando, J. J., and Soja, A. J.: The Fire INventory from NCAR (FINN): a high resolution global model to estimate the emissions from open burning, Geosci. Model Dev., 4, 625641, doi:10.5194/gmd-4-625-2011, 2011.

Wolfe, G. M., Kaiser, J., Hanisco, T. F., Keutsch, F. N., de Gouw, J. A., Gilman, J. B., Graus, M., Hatch, C. D., Holloway, J., Horowitz, L. W., Lee, B. H., Lerner, B. M., Lopez-Hilifiker, F., Mao, J., Marvin, M. R., Peischl, J., Pollack, I. B., Roberts, J. M., Ryerson, T. B., Thornton, J. A., Veres, P. R., and Warneke, C.: Formaldehyde production from isoprene oxidation across NOx regimes, Atmos. Chem. Phys., 16, 2597-2610, doi:10.5194/acp16-2597-2016, 2016.
Worden, H. M., Cheng, Y., Pfister, G., Carmichael, G. R., Zhang, Q., Streets, D. G., Deeter, M., Edwards, D. P., Gille, J. C., and Worden, J. R.: Satellite-based estimates of reduced $\mathrm{CO}$ and $\mathrm{CO}_{2}$ emissions due to traffic restrictions during the 2008 Beijing Olympics, Geophys. Res. Lett., 39, L14802, doi:10.1029/2012GL052395, 2012.

Worden, J., Jiang, Z., Jones, D., Alvarado, M., Bowman, K., Frankenberg, C., Kort, E. A., Kulawik, S. S., Lee, M., Liu, J., Payne, V., Wecht, K., and Worden, H.: El Niño, the 2006 Indonesian peat fires, and the distribution of atmospheric methane, Geophys. Res. Lett., 40, 4938-4943, doi:10.1002/grl.50937, 2013.

Yue, X., Unger, N., and Zheng, Y.: Distinguishing the drivers of trends in land carbon fluxes and plant volatile emissions over the past 3 decades, Atmos. Chem. Phys., 15, 11931-11948, doi:10.5194/acp-15-11931-2015, 2015.

Yurganov, L., McMillan, W., Grechko, E., and Dzhola, A.: Analysis of global and regional $\mathrm{CO}$ burdens measured from space between 2000 and 2009 and validated by ground-based solar tracking spectrometers, Atmos. Chem. Phys., 10, 3479-3494, doi:10.5194/acp-10-3479-2010, 2010.

Zimmerman, P., Greenberg, J., and Westberg, C.: Measurements of atmospheric hydrocarbons and biogenic emission fluxes in the Amazon boundary layer, J. Geophys. Res.-Atmos., 93, 14071416, doi:10.1029/JD093iD02p01407, 1988.

Zhu, L., Jacob, D. J., Mickley, L. J., Marais, E. A., Cohan, D. S., Yoshida, Y., Duncan, B. N., González Abad, G., and Chance, K. V.: Anthropogenic emissions of highly reactive volatile organic compounds in eastern Texas inferred from oversampling of satellite (OMI) measurements of HCHO columns, Environ. Res. Lett., 9, 114004, doi:10.1088/1748-9326/9/11/114004, 2014. 